\title{
The Relevance of Credit Ratings in Transparent Bond Markets
}

\author{
Dominique C. Badoer \\ University of Missouri
}

Cem Demiroglu

Koç University

March 13, 2018

\begin{abstract}
Mandated public dissemination of over-the-counter transactions in corporate debt securities via the TRACE system dramatically reduces the average short-term market reaction to rating downgrades by both issuer-paid and investor-paid rating agencies. Ratings become relatively more accurate predictors of default and more sensitive to innovations in credit spreads after the introduction of dissemination. However, in transparent markets, they provide no significant information about future defaults beyond that provided by credit spreads. Dissemination increases the efficiency of information aggregation and transmission in bond markets, thereby reducing the incremental information content of ratings and the price impact of rating revisions. (JEL D83, G14, G24)
\end{abstract}

This research is partially funded by financial support from the Robert J. Trulaske, Sr. College of Business Large Grant Program. We thank two anonymous referees; Philip Strahan (the editor), Christopher James, Oguzhan Ozbas, Narayan Bulusu (discussant); seminar participants at the Central Bank of the Republic of Turkey; and participants at 15th Paris December Finance Meeting for helpful comments. Send correspondence to Cem Demiroglu, College of Administrative Sciences and Economics, Koç University, Sariyer, Istanbul, Turkey 34450; telephone: +90-212-338-1620. E-mail: cdemiroglu@ku.edu.tr. 
Credit rating agencies are financial intermediaries that provide standardized opinions on the creditworthiness of debt issuers or specific debt obligations. They are believed to add value either by reducing investors' information processing costs or by transmitting material nonpublic information. When readily available to investors, bond prices perform a similar informational role, in the sense that they aggregate and reveal diverse pieces of default-relevant information held by various speculative traders. ${ }^{1}$

This paper examines how public dissemination of over-the-counter (OTC) trades in corporate debt securities affects the informativeness of credit ratings. Past theoretical and experimental research suggests that transparent markets aggregate and transmit information more rapidly and completely than opaque markets (Madhavan 1995; Pagano and Röell 1996; Bloomfield and O'Hara 1999). Building on this insight, we hypothesize that dissemination will increase the informational efficiency of bond prices, which, in turn, will reduce the incremental information content of credit ratings and the magnitude of stock and bond price reactions to changes in ratings.

We test this hypothesis using the introduction of TRACE, which publicly disseminates all OTC corporate bond transactions, as a quasi-random transparency shock. Before the introduction of TRACE, the corporate bond market was one of the least transparent securities markets in the United States. Neither dealer quotations nor completed transactions were reported broadly or continuously, resulting in substantial price uncertainty. Recent studies document significant reductions in bond trading costs and price dispersion after the introduction of TRACE, which implies that dissemination alleviates information asymmetries between dealers and investors and reduces the cross-sectional variation in the extent to which investors are informed about bond prices. $^{2}$

The introduction of TRACE provides a unique opportunity to study the informational effects of price transparency in OTC markets. The most useful feature of this setting from an identification standpoint is that dissemination was implemented in multiple phases between July 2002 and February 2005. This enables us to estimate its causal effects using a

\footnotetext{
${ }^{1}$ See Bond, Edmans, and Goldstein (2012) for an excellent review of both theoretical and empirical research that examines the informational role of security prices.

${ }^{2}$ See, for example, Bessembinder, Maxwell, and Venkataraman (2006), Bessembinder and Maxwell (2008), Edwards, Harris, and Piwowar (2007), Goldstein, Hotchkiss, and Sirri (2007), and Asquith, Covert, and Pathak (2013).
} 
difference-in-differences research design. Moreover, we have access to prices of both disseminated and nondisseminated historical bond transactions during the TRACE implementation period, which allows us to test whether the information content of bond prices and the responsiveness of ratings to innovations in prices depend on the transparency regime.

Past studies generally measure the informativeness of credit ratings using the short-term stock price reaction to announcements of rating revisions. ${ }^{3}$ The prevailing evidence is that rating downgrades (but not rating upgrades) convey valuable information to market participants, in the sense that, on average, they significantly move stock prices. ${ }^{4}$ Following the literature, we measure the informativeness of ratings using the short-term, that is, 3-day, stock price reaction to announcements of rating downgrades. Our sample consists of 1,617 bond rating downgrades by Standard \& Poor's, Moody's, and Fitch between July 1, 2001 (1 year before the introduction of TRACE) and February 7, 2006 (1 year after the full implementation of TRACE dissemination).

In univariate tests, we find that the average price impact of rating downgrades is $-2.9 \%$ for issuers with nondisseminated bonds and $-0.8 \%$ for those with disseminated bonds. The difference $(2.1 \%)$ is economically large and statistically significant at the $1 \%$ level. In the time-series, we find that the average quarterly announcement returns converge to zero as the fraction of disseminated bonds converges to one. These results are consistent with the hypothesis that the informativeness of ratings is substantially reduced in transparent bond markets. ${ }^{5}$

To identify the causal effect of dissemination, we estimate regressions with firm and year-quarter fixed effects using the full sample of downgrades. We also estimate separate difference-in-differences regressions using subsamples of downgrades just before and just after the introduction of each dissemination phase. To minimize concerns about omitted vari-

\footnotetext{
${ }^{3}$ See, for example, Holthausen and Leftwich (1986), Hand, Holthausen, and Leftwich (1992), Goh and Ederington (1993), Jorion, Liu, and Shi (2005), and Chava, Ganduri, and Ornthanalai (2016).

${ }^{4}$ Consistent with past studies, we find no significant price effect of rating upgrades, either before or after dissemination; as such, we focus on rating downgrades. The lack of a significant market reaction to upgrades is consistent with the view in Ederington, Yawitz, and Roberts (1987) that rating agencies expend more resources to detect deteriorations in credit quality than improvements. It is also consistent with the conjecture in Ederington and Goh (1998) that firms will voluntarily release favorable information before rating upgrades, but they will be reluctant to release unfavorable information before downgrades.

${ }^{5}$ While not reported, we find similar results using abnormal bond returns. Since abnormal return calculations require bonds to be traded continuously during the 3-day event window, and since most corporate bonds are traded infrequently, we are able to calculate abnormal bond returns for only $22.6 \%$ of our sample rating events.
} 
ables bias, we saturate our models with the two factors that determine the timing of dissemination (i.e., bond rating and size) as well as factors that have been shown by previous research to affect the stock price impact of rating revisions. We find that the multivariate effect of dissemination is economically larger than the univariate effect and statistically significant both in the full sample and around all three dissemination phases. These results are robust to (1) excluding rating downgrades that coincide with major firm-specific news announcements, (2) scaling abnormal stock returns by residual stock volatility, or (3) using alternative benchmark pricing models or event windows. Cross-sectionally, the effect of dissemination is diminished where stock analysts provide relatively more reliable earnings forecasts, suggesting that dissemination matters most where the uncertainty about credit risk is greatest. Taken together, these results indicate that the primary role of credit ratings is to fill information gaps in non-transparent debt markets. ${ }^{6}$

In related work, Chava et al. (2016) find that CDS trading reduces the informativeness of credit ratings. Since the CDS market experienced rapid growth during our sample period, it is important to separate the effects of dissemination from possible confounding effects of CDS trading. We find a similar effect of dissemination on firms that are referenced in CDS contracts compared to firms that are not, which indicates that CDS trading does not diminish the informational benefits of dissemination. Moreover, while we are able to replicate Chava et al. (2016)'s univariate results, the coefficient estimate on CDS trading in announcement effect regressions changes sign when we control for dissemination or include firm and time fixed effects, suggesting that Chava et al. (2016)'s estimates may suffer from omitted variables bias.

Next, we address a possible concern that the reductions in the informativeness of issuerpaid ratings after dissemination could arise from reductions in ratings quality. ${ }^{7}$ We find that the average market reaction to downgrades of investor-paid Egan-Jones ratings exhibits a sharp decline after dissemination, just like the average market reaction to downgrades of

\footnotetext{
${ }^{6}$ Jorion et al. (2005) argue that the exemption of credit rating agencies from Regulation Fair Disclosure (Regulation FD), which became effective in August 2000, increased the private information content in credit ratings. Consistent with this argument, they find an increase in the average stock price reaction to rating downgrades during August 2000 and December 2002. Our results suggest that, when transactions in bonds are publicly disseminated, the incremental private information content of an average rating downgrade is not large.

${ }^{7}$ Marandola and Mossucca (2016) speculate that corporate governance scandals in the early 2000s diminished investor confidence in rating agencies that are compensated by issuers.
} 
issuer-paid ratings. Also, we find no significant time trend during our sample period in the average stock price reaction to downgrades of private debt ratings by issuer-paid agencies. These two findings mitigate the concern that dissemination could be picking up unobserved changes in investor confidence in issuer-paid ratings.

We also find that issuer-paid ratings become more accurate predictors of future defaults and more sensitive to increases in credit spreads after dissemination, which suggests that our event study results are not driven by reductions in ex post ratings quality either. The improvement in the accuracy and timeliness of ratings after the introduction of dissemination is consistent with both (1) rating agencies incorporating the additional information learned from transparent bond prices into their models and (2) dissemination elevating rating agencies' reputational concerns by making it easier for investors to detect ratings inflation (Piccolo and Shapiro 2016).

We also examine the effect of dissemination on the information content of bond prices. We find that credit spreads become significantly more powerful predictors of default after dissemination, consistent with the theoretical predictions of Madhavan (1995) and Pagano and Röell (1996) and experimental evidence in Bloomfield and O'Hara (1999) that disclosing trading information to market participants increases the informational efficiency of security prices. Our results are also consistent with the evidence in a contemporaneous working paper by Chen and $\mathrm{Lu}$ (2017) that after the introduction of TRACE dissemination (1) bond return drift after bond analyst reports or credit rating revisions becomes shorter, (2) bond prices incorporate market information faster, and (3) bond prices more closely approximate random walks. ${ }^{8}$ The improvement in the predictive power of credit spreads is inconsistent with theories suggesting that dissemination will reduce price efficiency by leading informed investors to move their trades to less transparent markets (Bloomfield and O'Hara 2000) or by diminishing their incentives to collect private information (Diamond 1985).

Finally, we compare the ability of credit ratings and credit spreads to predict future defaults. We find that, before dissemination, credit ratings are more powerful predictors of

\footnotetext{
${ }^{8}$ Demiroglu, Franks, and Lewis (2017) find that, in U.S. Chapter 11 proceedings, bankruptcy courts take more account of bond prices after dissemination when updating their forecasts of the value of the reorganized firm. Moreover, they document that reliance on publicly disseminated bond prices dramatically reduces court misvaluations and virtually eliminates consequent interclaimant wealth transfers.
} 
default than are credit spreads. The reverse is true after dissemination. These results are consistent with the hypothesis that dissemination increases the informational efficiency of bond prices, and thereby reduces the incremental information content of credit ratings.

Our paper is related to several strands of research. First, we extend the empirical literature on the informativeness of credit ratings by presenting evidence that ratings are a substantially less relevant source of information where bond prices are readily available. We also show that the ability of ratings to predict future defaults as well as the sensitivity of ratings to innovations in market prices increases in transparent markets. Second, our paper contributes to the market microstructure literature which examines how trade transparency affects the information content of security prices. Because changes in transparency regimes are rare and hardly ever exogenous, subjecting theories on transparency to empirical tests has been difficult. Using the introduction of TRACE as an exogenous transparency shock, we find that dissemination increases the information content of bond prices, consistent with the theoretical predictions of Madhavan (1995) and Pagano and Röell (1996).

Our paper also contributes to literature on the costs and benefits of trade transparency. We find that a previously overlooked benefit of transaction reporting in debt markets is to reduce reliance on issuer-paid credit ratings which have been shown by past studies to result in distortions in firm financing and investment decisions (Baghai, Servaes, and Tamayo 2014; Harford, Martos-Vila, and Rhodes-Kropf 2015). Finally, our paper contributes to the literature that examines whether market-based indicators of credit risk are viable substitutes for credit ratings (see, e.g., Partnoy 1999; Flannery, Houston, and Partnoy 2010). Consistent with in-house research conducted by rating agencies, we find that, in transparent markets, market-based measures of credit risk are far more accurate predictors of default than agency ratings. ${ }^{9}$ However, in our empirical analyses, we do not separate credit spreads into default and nondefault components, and neither do we estimate the costs and benefits associated with greater accuracy versus false positives associated with market-based default indicators. Thus, more research is required to evaluate the substitutability of credit spreads and credit ratings.

\footnotetext{
${ }^{9}$ See, for example, Complementing Agency Credit Ratings with MIR (Market Implied Ratings) by Moody's Analytics at goo.gl/9QkXRA.
} 


\section{Background on TRACE}

In this section, we provide a brief overview of the microstructure of corporate bond markets and the implementation of TRACE. More detailed discussions are available in a number of sources, including Biais and Green (2007), Bessembinder and Maxwell (2008), and Asquith et al. (2013).

Corporate debt securities are generally traded in decentralized markets intermediated by dealers. Some trading activity occurs in the New York Stock Exchange (NYSE), but only a small fraction of bond issues are listed in the NYSE and a substantial fraction of the trades for the listed securities are carried out OTC (Hite and Warga 1997; Edwards et al. 2007). ${ }^{10}$

Prior to the implementation of TRACE, corporate debt markets were characterized by asymmetric information (Bessembinder and Maxwell 2008). There was limited pre-trade transparency (i.e., quotations, or prices at which dealers or other market participants are willing to trade, were not widely disseminated) or post-trade transparency (i.e., completed transactions were not systematically reported to third parties). ${ }^{11}$ As a result, institutional investors relied mainly on telephone quotations from dealers and price estimates ("matrix prices") from data vendors such as Merrill Lynch Bond Pricing Service or Interactive Data Corporation to estimate the value of their bond holdings. ${ }^{12}$ Individual investors had access to even less information and relied mainly on quotations from retail brokerage firms.

In 1998, the SEC called upon the National Association of Securities Dealers (NASD) to take the following three steps to provide greater transparency to investors and enhance the integrity of the corporate debt markets: “(1) adopt rules requiring NASD members to report all transactions in corporate bonds to the NASD and to develop systems to receive and distribute transaction prices on an immediate basis; (2) create a database of transactions in corporate bonds to enable regulators to take a proactive role in supervising the corporate

\footnotetext{
${ }^{10}$ Biais and Green (2007) provide evidence that before World War II, corporate bonds were actively traded on the NYSE, but trading largely migrated to OTC markets after the mid-1940s. They attribute the migration to increases in the relative importance of institutional investors who, the authors argue, preferred to avoid a public record of their large purchases and sales in part to reduce the risk of front-running.

${ }^{11}$ Such opacity is not necessarily a feature of dealer-oriented markets. For example, during our sample period, NASDAQ provided a greater level of both pre-trade and post-trade transparency.

${ }^{12}$ Matrix prices are algorithmically determined by adding a fixed spread to a frequently traded Treasury bond or by basing the price on bonds issued by similar firms (e.g., firms with similar credit ratings).
} 
debt market; and (3) create a surveillance program, in conjunction with the development of a database, to better detect fraud and foster investor confidence in the fairness of the corporate debt market." 13 In response, the NASD prepared and proposed the TRACE Rule 6210 which, after a number of amendments, was approved by the SEC in January 2001.

In July 1, 2002, the NASD introduced TRACE, an automated system that accommodates reporting and dissemination of OTC transactions in eligible corporate debt securities. ${ }^{14}$ All brokers/dealers registered with the SEC are mandated to report the transactions that they facilitate, as a principal or an agent, to TRACE shortly after execution. Reported information includes, among other things, the CUSIP number or FINRA symbol of the traded security, the date and time of execution, the transaction price, yield and volume (in dollars of par), and a symbol indicating whether the transaction is a buy or sell. ${ }^{15}$

For all eligible corporate debt securities, transaction reporting to TRACE began immediately on July 1 , 2002. ${ }^{16}$ However, the NASD implemented public dissemination in multiple phases because of the potential negative impact that dissemination could have on the liquidity of smaller, less actively traded issues. ${ }^{17}$ Figure 1 illustrates the implementation timeline (see Asquith et al. 2013 for additional details).

Phase I began on July 1, 2002, and required the dissemination of all transactions in investment-grade bonds with an original issue size of $\$ 1$ billion or greater, as well as 50 actively traded high-yield bonds which were carried over from the NASD's Fixed Income Pricing System (FIPS). By the end of 2002, transactions on 520 securities were being disseminated by TRACE. Phase II was implemented on March 3, 2003 and expanded public dissemination to include all bonds rated A- or better with an original issue size of at least $\$ 100$ million. An

\footnotetext{
${ }^{13}$ See https://www.sec.gov/rules/sro/nd9965n.htm.

${ }^{14}$ A TRACE-eligible security is a debt security that is (1) U.S. dollar-denominated, (2) issued by a U.S. or foreign private issuer, and (3) registered by the SEC or issued pursuant to Section 4(2) of the Securities Act of 1933 and purchased or sold pursuant to Rule 144A.

${ }^{15}$ The time delay to report a transaction was initially 75 minutes. NASD reduced it to 45 minutes on October 1 , 2003, to 30 minutes on October 1, 2004, and to 15 minutes on July 1, 2005. Since January 9, 2006, all transactions are reported immediately after execution.

${ }^{16}$ Initially, investors were able to access TRACE data free of charge through Web sites such as the National Association of Securities Dealers' (NASD's) nasdbondinfo.com or the Bond Markets Association's investinginbonds. com. Additionally, the data could be accessed through market data vendors such as Bloomberg and Reuters (Vames 2003). As of this writing, TRACE data are publicly available through http://finra-markets.morningstar. com/BondCenter/Default.jsp.

${ }^{17}$ Dissemination could reduce dealers' willingness to commit capital to risky or illiquid securities by reducing spreads and by making it more costly to unwind inventory after a large trade.
} 
additional $120 \mathrm{BBB}$ rated bonds with issue sizes less than $\$ 1$ billion were added as part of phase II in April 2003. ${ }^{18}$ With the implementation of phase II, the number of disseminated bonds increased to 4,650 . The last phase of TRACE was implemented in two stages. Phase IIIA became effective on October 1, 2004 and initiated transaction reporting in 9,558 new bonds rated BBB- or better. Phase IIIB became effective on February 7, 2005 and initiated dissemination for 3,016 new bonds rated BB+ or lower. ${ }^{19}$ According to the NASD, TRACE began disseminating $99 \%$ of all the transactions in eligible corporate debt securities after the completion of phase III.

In March 2010, FINRA publicly released an Enhanced TRACE data set that includes all disseminated and nondisseminated historical transactions. This data set allows us to examine whether dissemination affects (1) the information content of bond prices and (2) the sensitivity of credit ratings to bond prices. ${ }^{20}$

\section{Data}

The data used in this paper come from a variety of different sources. We obtain information on bond ratings and other bond characteristics from Mergent's Fixed Income Securities Database (FISD); secondary market bond transaction data from the Enhanced TRACE database (TRACE); daily stock returns from the Center for Research in Security Prices Daily Stock files (CRSP); monthly S\&P long-term issuer ratings, the date of quarterly earnings announcements, and quarterly firm financials from Compustat - Capital IQ North America (Compustat); analyst earnings forecasts from I/B/E/S Summary History files (IBES); credit default swap indicators from IHS Markit; information on firms' 8-K, 10-Q, and 10-K filings from the Securities and Exchange Commission's Electronic Data Gathering, Analysis, and Retrieval (EDGAR) system; and daily Treasury constant maturity rates as well as the monthly

\footnotetext{
${ }^{18}$ Goldstein et al. (2007) use these 120 BBB-rated bonds and a control sample of non-disseminated bonds to examine the effect of dissemination on liquidity.

${ }^{19}$ As part of phase IIIB, dissemination of transactions with a dollar volume exceeding $\$ 1$ billion in infrequently traded high-yield securities were subject to delay.

${ }^{20}$ The types of securities subject to TRACE reporting and dissemination have increased over time. According to TRACE Fact Book 2016, on March 1, 2010, TRACE began reporting transaction data for all U.S. agency debentures. Since May 16, 2011, TRACE has been collecting transactions in asset-backed and mortgage-backed securities. However, only transactions in agency pass through mortgage-backed securities (to-be-announced and specified pool transactions) are currently subject to dissemination. On June 30, 2014, transactions in SEC Rule 144A bonds became subject to dissemination. See http://www.finra.org/sites/default/files/2016-trace-fact-book.pdf.
} 
Consumer Price Index (CPIAUCSL) from FRED. We provide descriptions of the samples based on these data in subsequent sections and variable definitions in Table A1 (see the appendix).

\section{The Effect of Rating Downgrades on Stock Prices}

In this section, we examine how dissemination affects the informativeness of credit ratings by comparing the average short-term stock price reaction to announcements of rating downgrades before and after dissemination.

\subsection{Sample}

Our event study sample consists of 1,617 downgrades of corporate bond ratings (involving 472 unique issuers) by S\&P, Moody's, and Fitch (commonly referred to as the Big Three Nationally Recognized Statistical Rating Organizations (NRSRO)). Our sample period is between July 1, 2001 and February 7, 2006. Data on rating downgrades and bond characteristics come from FISD. A number of recent papers, including Jorion et al. (2005) and Chava et al. (2016), use the same database to examine the stock price impact of bond rating revisions.

We restrict our sample to dollar-denominated U.S. corporate debentures, medium-term notes, strips, zero coupon bonds, and bank notes without any credit enhancements. ${ }^{21} \mathrm{We}$ eliminate bonds with missing original amount, offering date, or scheduled maturity date, and require sample bonds to have at least one TRACE transaction record over the $(-31,-2)$ trading days preceding the downgrade; for downgrades prior to TRACE, we require the sample bonds to have at least one TRACE transaction record in 2002. When ratings on multiple outstanding bonds of an issuer are revised on the same day, we count the event only once and aggregate the relevant bond-level variables as described in Table A1 (see the appendix). We also exclude rating downgrades that are preceded by downgrades by other rating agencies in the past seven calendar days. Finally, we condition the sample on the availability of sufficient stock return data in CRSP to calculate the impact of the rating downgrade on the issuer's stock price.

\footnotetext{
${ }^{21}$ Following the past literature, we eliminate Rule144A private placements, convertible bonds, perpetual bonds, asset-backed bonds, mortgage-backed bonds, secured lease obligations, exchangeable bonds, foreign currency bonds, and Yankee bonds.
} 
Figure 2 provides the quarterly frequency distribution of rating downgrades in our event study sample. We group the downgrades by whether the issuer had disseminated bonds over the $(-31,-2)$ trading days prior to the downgrade. As shown, about a third of all the downgrades occur during the first four quarters of our sample period (before the introduction of TRACE). The clustering of downgrades in this period reflects, in part, the recession between March 2001 and November 2001 - downgrades tend to increase sharply toward the end of recessions (Amato and Furfine 2004). Moreover, the fraction of downgrades for issuers with disseminated bond transactions increases over time. The sample was constructed such that none of the downgrades in the first four quarters of our sample period are by firms with disseminated bonds, and all of the downgrades in the last four quarters of the sample period are by firms with disseminated bonds.

\subsection{Mean characteristics of downgrades by dissemination}

Table 1 provides a comparison of the mean characteristics of the subsamples of issuers with and without disseminated bonds. The list of variables in the table include (1) variables that have been shown by past studies to affect the stock price impact of rating downgrades and (2) variables that either affect or reflect the timing of TRACE dissemination.

As shown in Table 1, about $40 \%$ of the downgrades in our sample involve disseminated bonds. Because dissemination began earlier for larger and higher rated bonds, and earlier dissemination, ceteris paribus, increases the likelihood that a downgrade will occur after dissemination, we find that the mean firm rating and bond size are higher in the dissemination subsample than in the nondissemination subsample. Also, since the dissemination dummy has a positive time trend during our sample period, that is, the fraction of issuers with disseminated bonds increases over time, variables that exhibit a positive time trend over the same period (i.e., the CDS reference entity dummy, the contaminated announcement dummy, and the negative watch dummy) have a higher mean in the dissemination subsample than in the nondissemination subsample. ${ }^{22}$ In our regression analyses, we control for differences

\footnotetext{
${ }^{22}$ The proportion of downgrades in our sample involving CDS reference entities increases monotonically from $46 \%$ in 2001 to $83 \%$ in 2005 . The contaminated dummy has a positive time trend primarily because the number of 8-K filings exhibit a jump in 2004 when the SEC expanded the list of reportable events (see also https://www.sec. gov/rules/final/33-8400.htm). Finally, the proportion of downgrades preceded by a negative watch jumps from $16 \%$ in 2001 to $66 \%$ in 2002 and remains stable afterward; the increase in rating watches presumably reflect rating
} 
between the two groups of firms by including firm, bond, and rating characteristics as well as firm and time fixed effects.

\subsection{Estimation of abnormal stock returns}

To calculate cumulative abnormal daily stock returns associated with rating downgrades, we first estimate the $\beta$ coefficients for each stock $i$ using the following regression model:

$$
R_{i, t}=\alpha_{i}+\beta_{M, i} M k t R f_{t}+\beta_{S M B, i} S M B_{t}+\beta_{H M L, i} H M L_{t}+\beta_{U M D, i} U M D_{t}+\epsilon_{i, t}
$$

Here, $M k t R f, S M B, H M L$, and $U M D$ are the return benchmark factors due to Fama and French (1993) and Carhart (1997). They are, respectively, the excess return on the market portfolio over the risk-free rate, the return on small-minus-big firms, the return on highminus-low book-to-market ratio firms, and the return on winner-minus-loser stocks. The estimation window is trading days $(-251,-31)$ where day 0 is the date of the rating downgrade. If the downgrade occurs on a nontrading day, day 0 is the first subsequent trading day.

In the second step, we calculate the abnormal stock return for stock $i$ on day $t$ as:

$$
A R_{i, t}=R_{i, t}-\left[\widehat{\alpha_{i}}+\widehat{\beta_{M, i}} M k t R f_{t}+\widehat{\beta_{S M B}, i} S M B_{t}+\widehat{\beta_{H M L}, i} H M L_{t}+\widehat{\beta_{U M D}, i} U M D_{t}\right]
$$

Finally, we calculate the cumulative abnormal return $\left(C A R_{i}\right)$ for a stock as the sum of the $A R_{i, t}$ values during the three trading days centered on the date of downgrade (the event window). We require at least 63 nonmissing returns to estimate Equation (1) and three nonmissing returns in the event window to calculate $C A R_{i} \cdot{ }^{23}$ Finally, to reduce the influence of extreme outliers on our results, we winsorize $C A R_{i}$ at both the top and bottom $5 \%$ of its full sample distribution.

agencies' attempt to fend off criticisms after the Enron scandal that they are too slow to inform the market about changes in the riskiness of rated companies.

${ }^{23}$ Our results are not sensitive to the selection of the estimation window, event window, or the benchmark pricing model. Throughout the paper, we report the cross-sectional standard errors of the abnormal returns. All our results are robust to accounting for time-series or cross-sectional dependence in returns. The robustness tests are available on request. 


\subsection{Univariate results}

Figure 3 presents the quarterly averages of the cumulative abnormal stock returns over our sample period. Until the introduction of TRACE, the average abnormal returns are negative and exhibit a downward trend (they become bigger in absolute value). After the introduction of TRACE, they exhibit an upward trend. The reversal in the time trend around the introduction of TRACE means it is unlikely that the estimated effect of dissemination is coincidental. The average abnormal returns converge to zero as the fraction of disseminated transactions converge to one and remain stable at about $0 \%$ for at least a year after the full implementation of TRACE.

Table 2 provides a univariate analysis of the abnormal returns in the cross-section. Column 1 presents the results for the full sample of downgrades. As shown, the average abnormal return is $-2.87 \%$ for issuers in the nondissemination group and $-0.77 \%$ for issuers in the dissemination group; both averages are significantly different from zero at the $1 \%$ level. The difference between the two averages, which represents the estimated effect of dissemination, is $2.10 \%$ (significantly different from zero at the $1 \%$ level), indicating that dissemination reduces the stock price impact of rating downgrades by about $75 \%$.

Next, we split the full sample into three groups (phases I, II, and III) based on the first observed dissemination date of issuers' outstanding bonds. As shown in Columns 2 to 4 , in all three groups, the average stock price impact of rating downgrades is substantially diminished following the introduction of dissemination. The average reduction is $1.73 \%$ for phase I firms (58\% at the mean), $2.46 \%$ for phase II firms ( $83 \%$ at the mean), and $2.30 \%$ for phase III firms (almost 100\% at the mean). Also, during the post-dissemination period, the average announcement return is indistinguishable from zero for Phase II and Phase III firms. While not tabulated, we also find significant reductions in median abnormal returns as well as mean and median abnormal returns standardized by event period volatility. Taken together these results are consistent with the hypothesis that the incremental informational value of credit ratings is diminished in transparent bond markets. 


\subsection{Multivariate results}

We estimate the causal effect of dissemination using a difference-in-differences regression design. We start with regressions that utilize our full sample of rating downgrades. Next, we estimate regressions that use downgrades just before and just after the implementation of each dissemination phase.

3.5.1 Full sample regressions. Using our full sample of rating downgrades, we estimate the following regression:

$$
C A R_{i, t}=\alpha_{i}+\delta_{t}+\lambda \text { Dissemination }_{i, t}+\beta X_{i, t}+\epsilon_{i, t}
$$

Here, $\alpha_{i}$ and $\delta_{t}$ are firm- and time-specific intercepts, $X_{i, t}$ is a matrix of relevant controls, and $\epsilon_{i, t}$ is the error term. The estimated effect of dissemination is $\hat{\lambda}$. Equation (3) is a generalization of the standard difference-in-differences approach where the effect of a treatment is estimated by subtracting from the average change in the outcome variable after treatment the average change for a control group whose treatment status remained the same during the estimation window. In this specification, the control group is constructed from the average of all firms in the sample rather than from a different set of firms not experiencing a change in their dissemination status. ${ }^{24}$

An important advantage of the full sample analysis is that cross-sectional and time-series variations in dissemination, as well as a relatively large sample size, permit the use of firm and time fixed effects that help to reduce concerns about omitted variables bias. Firm fixed effects control for time-invariant differences in rating informativeness due to unexplained factors that differ across firms. The time fixed effects control for time-series changes in credit markets or investor confidence in rating agencies. Note that, by including time dummies, we attribute the time-series variation in announcement returns entirely to factors other than dissemination; thus it is possible that our estimates understate the true impact of dissemination.

\footnotetext{
${ }^{24}$ Jayaratne and Strahan (1996) and Bertrand, Duflo, and Mullainathan (2004) use similar specifications to estimate the causal effects of inter-state branching laws and state antitakeover laws, respectively, which were introduced at different times in different states.
} 
An additional advantage of this research design over a standard difference-in-differences approach is that it allows us to include firms for which the dissemination status changes multiple times during the sample period because of rating upgrades or downgrades as well as debt issuances and retirements. Moreover, the fact that the first dissemination date is at least 1 month after the official phase introduction for $44.5 \%, 61.3 \%$, and $20.0 \%$ of phase I, phase II, and phase III firms, respectively, complicates the use of a standard difference-in-differences research design in our setting.

Table 3 presents our estimation results. The dependent variable is the 3 -day cumulative abnormal stock return (as a percentage) in all columns except for Column 5, where we use the standardized abnormal return (or SCAR), defined as the cumulative abnormal return scaled by the daily estimation window residual stock return volatility (Jorion et al. 2005). All the regressions are estimated via ordinary least squares (OLS). The standard errors of the regression coefficients are heteroscedasticity-consistent and clustered at the firm level.

Column 1 presents a univariate specification where the estimated coefficient on dissemination is identical to the univariate estimate reported in Table 2 and serves as a benchmark for the multivariate specifications. In Column 2, in addition to firm and time fixed effects, our model includes variables that have been shown in past studies to affect the stock price reaction to rating downgrades (e.g., size of rating change, time since last downgrade) as well as factors that affect the timing of dissemination (e.g., rating, bond size (and its square)). As shown, the coefficient estimate on dissemination increases from $2.10 \%$ in the univariate specification in Column 1 to $2.76 \%$ in the multivariate specification in Column 2 (both coefficient estimates are statistically significant at the $1 \%$ level).

In column 3, we replace the dissemination dummy with interaction terms between phase I, phase II, and phase III dummies and the dissemination dummy. The omitted group in Column 3 consists of downgrades involving firms that did not have any disseminated bonds during our sample period, that is, firms that were downgraded before full implementation of TRACE and were not downgraded subsequently or firms that retired their publicly traded bonds before the introduction of dissemination. The coefficient estimates on all three interaction terms are statistically significant and economically large, which suggests that rating informativeness is reduced after dissemination for issuers in all three dissemination phases. 
In Columns 4 to 6 , we conduct a number of robustness checks using the same specification used in Column 2. For example, in Column 4, we exclude rating announcements that are contaminated with contemporaneous firm-specific news announcements. In Column 5, we use SCAR as our dependent variable to mitigate a possible concern that the effect of dissemination could reflect cross-sectional differences in return volatility. In Column 6, to avoid confounding the effect of dissemination with unobserved shocks that affect rating informativeness, we restrict the estimation sample to downgrades that occur within 6 months of the first dissemination date for each sample issuer. None of these robustness checks affect the sign or the significance of the dissemination dummy. Overall, the evidence in Table 3 provides strong support to the hypothesis that dissemination reduces the relevance of credit ratings.

Chava et al. (2016) find that CDS trading significantly reduces the informativeness of rating downgrades. In Columns 2 through 6 of Table 3, we find a remarkably different result; the coefficient on CDS trading is negative in all the specifications. We examine the effect of CDS trading more carefully in the Internet Appendix. As shown in the Internet Appendix, just like Chava et al. (2016), we find in univariate specifications that dissemination reduces the average stock price reaction to rating downgrades by about 50\% (significant at the $1 \%$ level). However, when we control firm, bond, and rating characteristics, the coefficient estimate on CDS trading drops from 1.41 to 0.44 and becomes insignificant. When we also control for dissemination and include firm and time fixed effects in our models, the coefficient estimate on CDS trading changes sign and becomes negative. These results suggest that the estimated effect of CDS trading in Chava et al. (2016) may suffer from omitted variables bias.

3.5.2 Difference-and-difference regressions around phase introductions. An important advantage of the full sample analysis is that the sample size is large enough to accommodate specifications with firm fixed effects which help reduce potential concerns about omitted variables bias. However, analyzing the effect of dissemination separately around the introduction of each phase would provide further assurance that we are indeed capturing the effect of dissemination and not picking up the effect of an omitted variable that is correlated with both dissemination and announcement returns.

We estimate the following difference-in-differences regression using a sample of rating 
downgrades before and after each phase introduction:

$$
C A R_{i, t}=\alpha+\gamma_{1} \text { Treatment }_{i} \times \text { Post }_{t}+\gamma_{2} \text { Treatment }_{i}+\gamma_{3} \text { Post }_{t}+\epsilon_{i, t}
$$

Here, Treatment $_{i}$ is an indicator for whether the firm changes dissemination status (i.e., whether it is in the treatment group or the control group) and Post $t_{t}$ is an indicator for rating downgrades that occur after phase introductions. $\widehat{\gamma_{2}}$ captures pre-existing differences between firms that change dissemination status and those that do not. $\widehat{\gamma_{3}}$ captures time-series changes in announcement returns that influence both disseminated and nondisseminated firms. The coefficient of interest is $\widehat{\gamma_{1}}$, the estimated effect of dissemination on announcement returns.

Identification in this setting is based on two critical assumptions. First, there must be no other change simultaneous with phase introductions that affects the announcement returns of treated firms but not the announcement returns of control firms. Second, the change over time in the announcement returns of control firms must reveal what would have occurred to treated firms if there had been no change in their dissemination status. Note that this assumption does not mean that control firms must have the same characteristics as treated firms; rather, it means that changes in the announcement returns of control firms capture the counterfactual time path of the announcement returns of treated firms.

Our empirical methodology requires that we specify an estimation window around phase introductions. In choosing the proper window, we face a trade-off: Choosing a window that is too long may increase the probability that our identification assumptions are violated because of confounding factors; however, choosing too short a window may leave us with a sample that is too small to conduct powerful tests. To strike a balance between these two concerns, we use a 2-year estimation window centered on phase introductions; however, because the distance between phase I and phase II is only eight months, we restrict the post-estimation (pre-estimation) period for phase I (II) to 8 months.

Table 4 presents our first set of results. Here, the control group consists of all firms that do not experience a change in their dissemination status during the estimation window. For example, when estimating the effect of dissemination for phase I firms (the treatment group), the control group consists of phase II and phase III firms. The odd-numbered columns in 
the table provide parsimonious specifications that only include the dissemination dummy, the post dummy, and the interaction between the two. In even-numbered columns, we saturate our models with the same set of bond and rating controls used in Table 3 as well as yearquarter fixed effects to reduce residual variance. Standard errors of the regression coefficients are clustered at the firm level.

As shown in Table 4, the estimated effect of dissemination on announcement returns, $\widehat{\gamma_{1}}$, is positive and statistically significant in all six columns. Based on the coefficient estimates reported in Columns 1, 3, and 5, the reduction in the price impact of rating downgrades is about $3.8 \%$ for issuers in phase I, $3.4 \%$ for issuers in phase II, and $2.2 \%$ for issuers in phase III. That $\widehat{\gamma_{1}}$ remains almost the same when we include bond and rating controls as well as time fixed effects in our models mitigates concerns about omitted variables bias. ${ }^{25}$ Overall, the evidence in Table 4 reinforces the conclusion in Section 3.5.1 that dissemination dramatically reduces the informativeness (or relevance) of credit ratings.

One concern with the identification strategy in Table 4 is that downgrades in our control groups might not always provide an adequate counterfactual for downgrades in our treatment groups. For example, downgrades of small, high-yield phase III bonds might not serve as suitable controls for downgrades of large, investment-grade phase I bonds (and vice versa). To address this concern and create a more focused causal inference, we conduct a matched difference-in-differences analysis where we compare treatment groups with a select group of control firms with similar ratings. ${ }^{26}$ For example, we use downgrades of large, investmentgrade rated phase I and phase II bonds as benchmarks against each other. We also use downgrades of high-yield phase III-B bonds as a benchmark against downgrades of high-yield phase I bonds (also known as FIPS 50 bonds). Because there are no natural benchmarks in our bond sample for downgrades of relatively small phase III bonds some of which are rated

\footnotetext{
${ }^{25}$ The coefficient estimate on the indicator variable post $\left(\widehat{\gamma_{3}}\right)$ is unidentified in Columns 2 and 6 since there is no within year-quarter variation in this variable in the phase I and the phase III subsamples. However, it is identified in Column 4 because in the phase II subsample there is variation in the post dummy during the first quarter of 2003.

${ }^{26}$ Unfortunately, our sample is not large enough to form exact-matched pairs of treatment and control firms based on multiple firm and bond characteristics. Moreover, because bonds were assigned into dissemination phases based on rating and size, it is not feasible to match treatment and control groups based on both of these variables. We match treatment and control groups based on rating rather than on size because, in unreported results, we find a significant correlation between announcement returns and ratings but no significant relation between announcement returns and bond size.
} 
below investment grade, we use downgrades of private debt issues recorded by S\&P's RatingXpress database as benchmarks; critically, we require issuers of private claims to have no disseminated bonds in the month prior to the downgrade.

Table 5 reports our estimation results. Panel A presents our parsimonious specifications and Panel B presents specifications with additional controls. As shown, despite the small size of our estimation samples, the key coefficient of interest, $\widehat{\gamma_{1}}$, is positive and both statistically significant and economically large around in three phases. Overall, the results in Tables 3,4 , and 5 all indicate that corporate credit ratings become substantially less relevant in the presence of readily available bond prices. The robustness of our results to different estimation strategies and sampling criteria substantially limits the scope of alternative explanations for our findings.

\subsection{Dissemination or reduced confidence in ratings?}

Bar-Isaac and Shapiro (2013) model the reputational costs of providing lower quality ratings for issuer-paid rating agencies and predict that ratings quality will be lower during economic booms than during recessions (see Dilly and Mählmann 2016 for empirical evidence consistent with this prediction). ${ }^{27}$ If investors recognize that the quality of ratings varies across the business cycle, their model could offer an alternative explanation for why the average price impact of rating downgrades falls during the latter part of our sample period, when the U.S. economy was expanding. We believe the inclusion of year-quarter fixed effects in our regression models mitigates a possible concern that the estimated effect of dissemination reflects time-series changes in ex ante ratings quality (or reduced confidence in ratings). Nonetheless, we employ two empirical tests designed to examine this issue directly.

First, we examine how dissemination affects the price impact of downgrades from an investor-paid rating agency, Egan-Jones Ratings (EJR). Since EJR is compensated by investors, not by issuers, the quality of its ratings should be less susceptible to economic cycles as long as investors' demand for accurate ratings is relatively stable. Therefore, we would not expect to find different market reactions to EJR downgrades of disseminated and nondissem-

\footnotetext{
${ }^{27}$ They characterize economic booms by low overall default probabilities and tighter competition in the labor market for qualified credit analysts.
} 
inated firms unless dissemination reduces the incremental informativeness of credit ratings.

Unlike the Big Three issuer-paid rating agencies, EJR does not rate individual bonds but solely provides issuer ratings. During our sample period, there are 919 rating downgrades by EJR involving one of the issuers in our main event study sample. As shown in Table 6, based on the coefficients of our baseline fixed effect specification reported in Column 2, dissemination reduces the average stock price impact of EJR downgrades by almost 4\%, which is inconsistent with the view that dissemination serves as a proxy for reduced investor confidence in issuer-paid ratings during economic booms.

Second, we examine the market reaction to downgrades of private debt ratings by issuerpaid agencies. Using S\&P's RatingXpress database, we identify 607 downgrades of private debt issues where the issuer had no outstanding bonds subject to TRACE dissemination during the 30 trading days preceding the downgrade. If investors have less confidence in issuerpaid ratings during the second half of our sample period, we would expect the average market reaction to rating downgrades to fall in this period for both public bonds and private debt issues. However, as shown in Figure 4, we find that the quarterly average stock price impact of downgrades of private debt issues remains relatively stable during the TRACE implementation period. Finding no significant time-series reduction in the informativeness of rating downgrades for a group of issues not treated by dissemination increases our confidence that we estimate the causal effect of dissemination in Tables 3,4 , and 5 .

Finally, while not tabulated, we also examine the stock price reaction to downgrades of private debt issues for issuers with bonds that are subject to dissemination through TRACE. In 251 cases where transactions in the issuer's bonds are publicly disseminated, the average abnormal stock return associated with the rating downgrade is $-1.81 \%$ (significant at the $1 \%$ level). In the remaining 607 cases where bond transactions are not disseminated, the average abnormal stock return is $-4.67 \%$ (significant at the $1 \%$ level). The difference is $2.85 \%$ and is economically large and statistically significant at the $1 \%$ level, suggesting that the disclosure of bond transactions reduces price uncertainty not only in the corporate bond market but also in private debt markets. 


\subsection{Cross-sectional variation in the effect of dissemination}

In this section, we examine the cross-sectional variation in the effect of dissemination on the stock price reaction to rating downgrades. Table 7 reports our results. In addition to a set of relevant controls, each regression in the table includes a dissemination dummy, an information measure (e.g., low analyst forecast dispersion), and the interaction term between the dissemination dummy and the information measure. To facilitate the interpretation of the coefficient estimates, we use binary information measures. For example, in Column 1, low analyst forecast dispersion is a binary variable that equals one if analyst forecast dispersion, as defined in Table A1 (see the appendix), is below the sample median. The coefficient estimate on the dissemination dummy in this column shows the average effect of dissemination for the subsample of firms with relatively high analyst forecast dispersion, conditional on other controls. The coefficient estimate on the interaction term shows the difference in the effect of dissemination on firms with low versus high forecast dispersion. Finally, the sum of the coefficient estimate on the dissemination dummy and the coefficient estimate on the interaction term (reported at the bottom of the table) shows the effect of dissemination on firms with relatively low analyst forecast dispersion.

As shown in Columns 1 and 2, we find that dissemination has a significant effect only on firms with high analyst forecast dispersion or error, which suggests that dissemination matters only where the uncertainty about the issuer's future prospects or credit risk is large.

In Column 3, we compare the effect of dissemination on investment-grade firms and highyield firms. We find that the effect of dissemination on investment-grade firms (1.48\%) is about 50\% lower than the effect of dissemination on high-yield firms (3.18\%); the difference is statistically significant at the $5 \%$ level. The evidence is consistent with the finding in Huang and Huang (2012) that credit risk is a much smaller component of credit spreads for investment-grade firms than it is for high-yield firms.

In Column 4, we find that whether or not one or more of the downgraded bonds is exchange listed does not reduce the effect of dissemination. Warga and Welch (1993) find that even for exchange listed bonds a substantial majority of the trades occurs in OTC markets, and the small fraction of trades that take place on exchanges generally involve uninformed retail in- 
vestors. As a result, exchange listing might not serve as a substitute for the public disclosure of OTC transactions.

Finally, in Column 5, we examine how the effect of dissemination varies with CDS trading. We find that dissemination reduces the average announcement returns by $2.03 \%$ in the no CDS subsample ( $t$-stat=2.30) and $1.85 \%(t$-stat=2.96) in the CDS subsample. The difference between the two averages is economically small and statistically insignificant $(t$-stat=0.20), suggesting that, in our context, CDS trading does not reduce the informational benefits of dissemination.

\section{Information Content of Credit Ratings and Credit Spreads}

In this section, we investigate whether the information content of credit ratings and credit spreads depends on the transparency regime, using a monthly panel of issuer ratings and trade-weighted average credit spreads.

\subsection{Sample}

In our estimations, we use an unbalanced monthly panel data set which consists of 16,135 observations (431 unique firms and 44 unique months). The sample period is between July 2002 and February 2006. The sample is restricted to issuers with at least one rating change in Mergent during our sample period, and includes only issuers with at least 3 months of disseminated and 3 months of nondisseminated historical bond transactions in TRACE. We exclude firm-months in which the issuer rating is missing or equal to "CC," "C," "SD" (selective default), and "D" (default). In specifications controlling for firm financial characteristics, we lose additional observations due to missing quarterly Compustat data. The frequency of phase I, phase II, and phase III firms in our sample is $29.7 \%, 37.8 \%$, and $32.5 \%$, respectively. The definitions of all the variables we use in our panel data analysis are available in panel B of Table A1 (see the appendix). 


\subsection{The ability of ratings and spreads to predict future defaults}

We examine the effect of dissemination on the incremental information content of credit ratings and credit spreads by comparing the ability of both variables to predict future defaults before and after dissemination. The dependent variable in our default models is a binary variable that equals one if (1) at any point in time in the next 3 calendar years the issuer's long-term S\&P rating is downgraded to "C," "D," or "SD"; (2) one or more of the issuer's bonds are downgraded to "C" or " $\mathrm{D}$ " by S\&P, Moody's, or Fitch or (3) the issuer defaults on a debt obligation or files for bankruptcy. The average three-year cumulative default rate in our firmmonth sample is $2.54 \% .{ }^{28}$ Our results are robust to using defaults within 1,2 , or 5 years.

Table 8 presents our estimation results. In Columns 1 and 2, we examine how dissemination affects the ability of credit ratings to predict future defaults. We convert alphanumeric issuer ratings into numerical values such that higher numerical ratings imply higher credit quality (CC (1), CCC- (2),.., AA+ (19), AAA (20)); thus we would expect to find a negative relation between numerical ratings and the likelihood of default. In our analysis, we use firm-level ratings instead of bond-level ratings because our data set is at the firm level and default is generally a firm-level event.

Column 1 reports a parsimonious specification that only includes a dissemination indicator, the natural logarithm of the issuer's end-of-month credit rating, and the interaction term between dissemination and rating. ${ }^{29}$ In Column 2, we saturate our model with additional controls, including firm financial characteristics, phase fixed effects, industry fixed effects, and time fixed effects. In both columns, the coefficient estimate on the rating measure shows the relation between the issuer rating and ex post likelihood of default in the pre-dissemination period. The coefficient estimate on the interaction term shows how this relation changes after dissemination. As shown, we find that the coefficient estimate on the dissemination dummy is negative and statistically significant, which indicates that, in opaque markets, better-rated firms are less likely to default. Also, the coefficient estimate on the interaction term between dissemination and rating is negative and statistically significant, which indicates that ratings

\footnotetext{
${ }^{28}$ About $5.8 \%$ of the unique firms in our panel data set experience a default. Since firms that do not default on their debt remain in our sample longer, the average default rate in the firm-month sample is lower than 5.8\%.

${ }^{29} \mathrm{We}$ take the natural logarithm of the numerical ratings because a one-unit rating change has a bigger effect on the likelihood of default at lower ratings.
} 
become more powerful predictors of future defaults after dissemination. This result mitigates the concern that the decline in the informativeness of ratings after dissemination may be driven by reductions in ratings accuracy.

In Columns 3 and 4, we examine how well credit spreads predict future defaults before and after dissemination. We find that the coefficient estimate on spread is positive and significant, which indicates that, in opaque markets, firms with higher credit spreads are more likely to default ex post. We also find that the coefficient estimate on the interaction term between dissemination and spread is positive and statistically significant, which indicates that, just like ratings, credit spreads become more powerful predictors of default after dissemination. Overall, the results in Columns 3 and 4 are consistent with the theoretical predictions of Madhavan (1995) and Pagano and Röell (1996) and the experimental evidence in Bloomfield and O'Hara (1999) that the disclosure of transactions will increase the informational efficiency of security prices by enhancing the speed of information aggregation. They are also consistent with the empirical evidence in Chen and Lu (2017) that mandated transaction reporting via the TRACE system increases the informational efficiency of corporate bond prices. ${ }^{30}$

Before turning to the relative informativeness of credit ratings and credit spreads, several comments are in order. First, the coefficient estimates on the interaction terms reported in Columns 1 through 4 of Table 8 do not appear to be sensitive to the inclusion of industry, year-quarter, and phase fixed effects as well as a large number of firm-level controls. This mitigates potential concerns about omitted variables bias. ${ }^{31}$ Second, Das, Kalimipalli, and Nayak (2014) find that CDS trading adversely affects the informational efficiency of bond prices, which raises a concern that the informational benefits of dissemination might be offset by CDS trading. However, as shown in the Internet Appendix, the effect of dissemination in the CDS subsample is almost identical to that in the full sample.

In Columns 5 and 6 , we run a horse race between credit ratings and 1-month lagged credit spreads. As shown in Column 5, we find that, before dissemination, the coefficient estimate on $\ln$ (Rating) is negative and statistically significant, which indicates that credit ratings are

\footnotetext{
${ }^{30}$ Lewis (2017), on the other hand, finds that bond return drifts become longer after dissemination.

${ }^{31}$ Because corporate default rates were relatively low during our sample period, difference-in-differences regressions that compare the change in the ability of ratings (or spreads) to predict future defaults around the introduction of individual dissemination phases for subsamples of treatment and control firms will not yield powerful results.
} 
incrementally informative about future defaults in opaque markets. However, as shown in Column 6, after dissemination, the coefficient estimate on $\ln$ (Rating) becomes much smaller in magnitude and statistically insignificant, which implies that, in transparent markets, credit ratings have no incremental predictive power relative to credit spreads. The reduction in the informativeness of credit ratings after dissemination appears to arise from a substantial increase in the informativeness of credit spreads. Specifically, while the coefficient estimate on credit spreads is insignificant before dissemination (Column 5), it becomes far larger and statistically significant (at the 1\% level) after dissemination (Column 6). Overall, the results in Table 8 are consistent with the view that after the bond market becomes more transparent, bond prices become more efficient and this, in turn, reduces the incremental information content of credit ratings.

\subsection{The responsiveness of credit ratings to changes in credit spreads}

In our final set of regressions reported in Table 9, we examine the responsiveness of credit ratings to credit spreads both before and after dissemination.

In Column 1, we estimate the contemporaneous correlation between credit ratings and credit spreads using OLS. The dependent variable is the natural logarithm of firm-level numerical rating. Explanatory variables include spread, dissemination, and spread times dissemination. To minimize unobserved heterogeneity, we saturate our model with firm and time fixed effects as well as firm financial characteristics. Standard errors are double clustered by firm and time.

As shown, the coefficient estimate on spread is negative and statistically significant, which indicates that, prior to dissemination, firms with higher credit spreads on average have poorer ratings. Also, the coefficient estimate on the interaction term between spread and dissemination is negative and statistically significant, which indicates that the conditional correlation between credit ratings and credit spreads increases after dissemination. ${ }^{32}$

In Columns 2 and 3, we examine the relation between credit spreads and the likelihood of rating downgrades and rating upgrades, respectively. As shown in Column 2, dissemination

\footnotetext{
${ }^{32}$ As shown in the Internet Appendix, our results are robust to using ordered logit (without firm fixed effects) instead of OLS.
} 
significantly increases the likelihood of rating downgrades in response to increases in credit spreads. Rating upgrades, however, do not appear to be related to lagged innovations in credit spreads before or after dissemination.

Overall, the results in Table 9 indicate that, after dissemination, credit ratings become significantly more sensitive to credit spreads. One explanation is that rating agencies incorporate default-relevant information that they learn from transparent bond prices into their models. Also, the asymmetry between rating downgrades and upgrades in terms of their responsiveness to changes in credit spreads after dissemination is consistent with the theoretical predictions of Piccolo and Shapiro (2016); they argue that more informative market trading makes rating inflation more transparent, and therefore increases the incentives for rating agencies to update their ratings in a more timely manner.

\section{Conclusion}

This paper examines how mandated price transparency in the secondary market for corporate bonds affects the informativeness of credit ratings. We find that public dissemination of information on completed transactions dramatically reduces the informativeness of ratings. This finding does not appear to be driven by reductions in ex ante or ex post ratings quality. We also find that, after dissemination, bond prices are more accurate predictors of default than are credit ratings, and that ratings contain little, if any, incremental information relative to prices. Finally, we find that dissemination enhances the aggregation of default-relevant information in bond prices. These results have implications for policy debates on mandated transparency regulations in OTC markets and the use of market-based indicators of credit risk as substitutes for credit ratings in financial regulation.

\section{Appendix A. Variable Definitions}




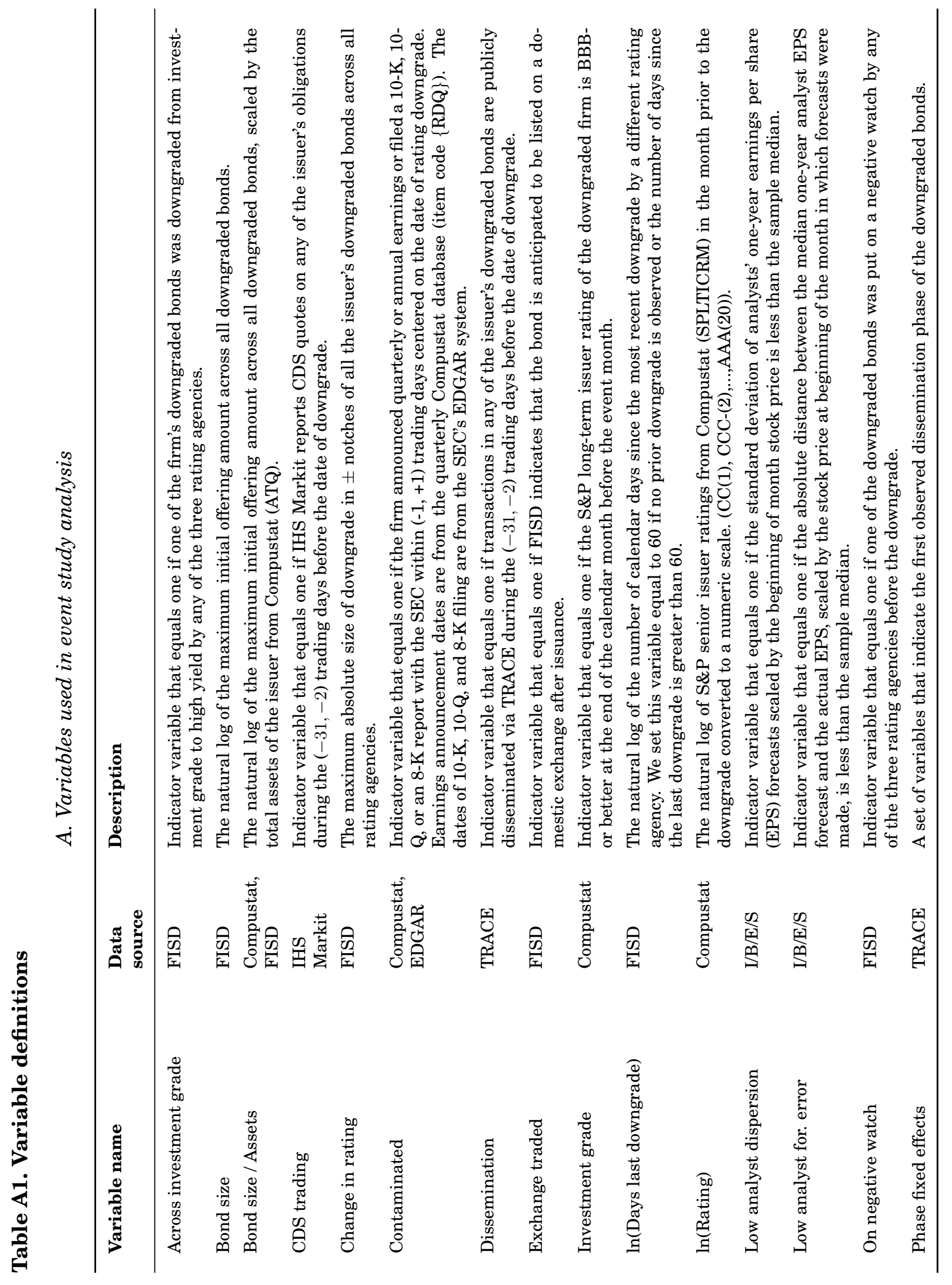




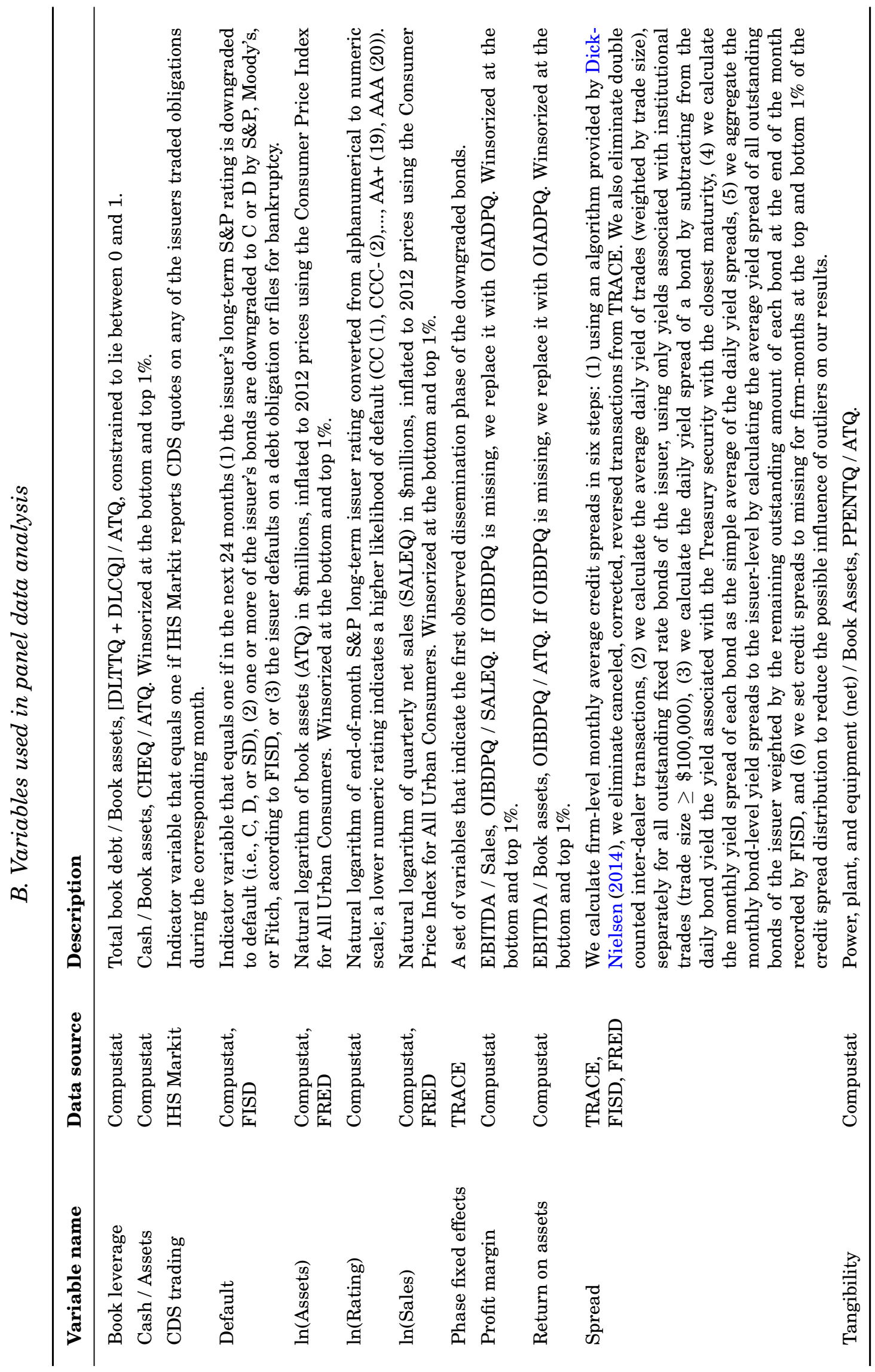




\section{References}

Amato, J. D., and C. H. Furfine. 2004. Are credit ratings procyclical? Journal of Banking and Finance 28:2641-77.

Asquith, P., T. Covert, and P. Pathak. 2013. The effects of mandatory transparency in financial market design: Evidence from the corporate bond market. Working Paper, MIT Sloan School of Management.

Baghai, R. P., H. Servaes, and A. Tamayo. 2014. Have rating agencies become more conservative? Implications for capital structure and debt pricing. Journal of Finance 69:1961-2005.

Bar-Isaac, H., and J. Shapiro. 2013. Ratings quality over the business cycle. Journal of Financial Economics 108:62-78.

Bertrand, M., E. Duflo, and S. Mullainathan. 2004. How much should we trust differences-indifferences estimates? Quarterly Journal of Economics 119:249-75.

Bessembinder, H., and W. F. Maxwell. 2008. Transparency and the corporate bond market. Journal of Economic Perspectives 22:217-34.

Bessembinder, H., W. F. Maxwell, and K. Venkataraman. 2006. Market transparency, liquidity externalities, and institutional trading costs in corporate bonds. Journal of Financial Economics 82:251-88.

Biais, B., and R. C. Green. 2007. The microstructure of the bond market in the 20th century. Working Paper, Carnegie Mellon University.

Bloomfield, R., and M. O'Hara. 1999. Market transparency: Who wins and who loses? Review of Financial Studies 12:5-35.

- 2000. Can transparent markets survive? Journal of Financial Economics 55:425-59.

Bond, P., A. Edmans, and I. Goldstein. 2012. The real effects of financial markets. Annual Review of Financial Economics 4:339-60. 
Carhart, M. M. 1997. On persistence in mutual fund performance. Journal of Finance 52:5782.

Chava, S., R. Ganduri, and C. Ornthanalai. 2016. Are credit ratings still relevant? Working Paper, Georgia Institute of Technology.

Chen, J., and R. Lu. 2017. Pricing efficiency and market transparency: Evidence from corporate bond market. Working Paper, Guanghua School of Management.

Das, S., M. Kalimipalli, and S. Nayak. 2014. Did CDS trading improve the market for corporate bonds? Journal of Financial Economics 111:495-525.

Demiroglu, C., J. R. Franks, and R. Lewis. 2017. Do market prices improve the accuracy of court valuations in Chapter 11? Working Paper, Koç University.

Diamond, D. W. 1985. Optimal release of information by firms. Journal of Finance 40:107194.

Dick-Nielsen, J. 2014. How to clean enhanced TRACE data. Working Paper, Copenhagen Business School.

Dilly, M., and T. Mählmann. 2016. Is there a boom bias in agency ratings? Review of Finance 20:979-1011.

Ederington, L. H., and J. C. Goh. 1998. Bond rating agencies and stock analysts: Who knows what when? Journal of Financial and Quantitative Analysis 33:569-85.

Ederington, L. H., J. B. Yawitz, and B. E. Roberts. 1987. The informational content of bond ratings. Journal of Financial Research 10:211-26.

Edwards, A. K., L. E. Harris, and M. S. Piwowar. 2007. Corporate bond market transaction costs and transparency. Journal of Finance 62:1421-51.

Fama, E. F., and K. R. French. 1993. Common risk factors in the returns on stocks and bonds. Journal of Financial Economics 33:3-56.

Flannery, M. J., J. F. Houston, and F. Partnoy. 2010. Credit default swap spreads as viable substitutes for credit ratings. University of Pennsylvania Law Review 158:2085-123. 
Goh, J. C., and L. H. Ederington. 1993. Is a bond rating downgrade bad news, good news, or no news for stockholders? Journal of Finance 48:2001-8.

Goldstein, M. A., E. S. Hotchkiss, and E. R. Sirri. 2007. Transparency and liquidity: A controlled experiment on corporate bonds. Review of Financial Studies 20:235-73.

Hand, J. R., R. W. Holthausen, and R. W. Leftwich. 1992. The effect of bond rating agency announcements on bond and stock prices. Journal of Finance 47:733-52.

Harford, J., M. Martos-Vila, and M. Rhodes-Kropf. 2015. Corporate financial policies in overvalued credit markets. Working Paper, University of Washington.

Hite, G., and A. Warga. 1997. The effect of bond-rating changes on bond price performance. Financial Analysts Journal 53:35-51.

Holthausen, R. W., and R. W. Leftwich. 1986. The effect of bond rating changes on common stock prices. Journal of Financial Economics 17:57-89.

Huang, J., and M. Huang. 2012. How much of the corporate-Treasury yield spread is due to credit risk? Review of Asset Pricing Studies 2:153-202.

Jayaratne, J., and P. E. Strahan. 1996. The finance-growth nexus: Evidence from bank branch deregulation. Quarterly Journal of Economics 111:639-70.

Jorion, P., Z. Liu, and C. Shi. 2005. Informational effects of regulation FD: Evidence from rating agencies. Journal of Financial Economics 76:309-30.

Lewis, R. 2017. Precisely inaccurate: The impact of mandatory transparency on price informativeness. Working Paper, University of Colorado.

Madhavan, A. 1995. Consolidation, fragmentation, and the disclosure of trading information. Review of Financial Studies 8:579-603.

Marandola, G., and R. Mossucca. 2016. When did the stock market start to react less to downgrades by Moody's, S\&P and Fitch? Working Paper, University of Bologna.

Pagano, M., and A. Röell. 1996. Transparency and liquidity: A comparison of auction and dealer markets with informed trading. Journal of Finance 51:579-611. 
Partnoy, F. 1999. The Siskel and Ebert of financial markets: Two thumbs down for the credit rating agencies. Washington University Law Quarterly 77:619-712.

Piccolo, A., and J. Shapiro. 2016. Credit ratings and market information. Working Paper, Oxford University.

Vames, S. 2003. In a major shift, NASD expands corporate bond-price reports. Wall Street Journal, March 3. https://www.wsj.com/articles/SB1046714678626958720.

Warga, A., and I. Welch. 1993. Bondholder losses in leveraged buyouts. Review of Financial Studies 6:959-82. 


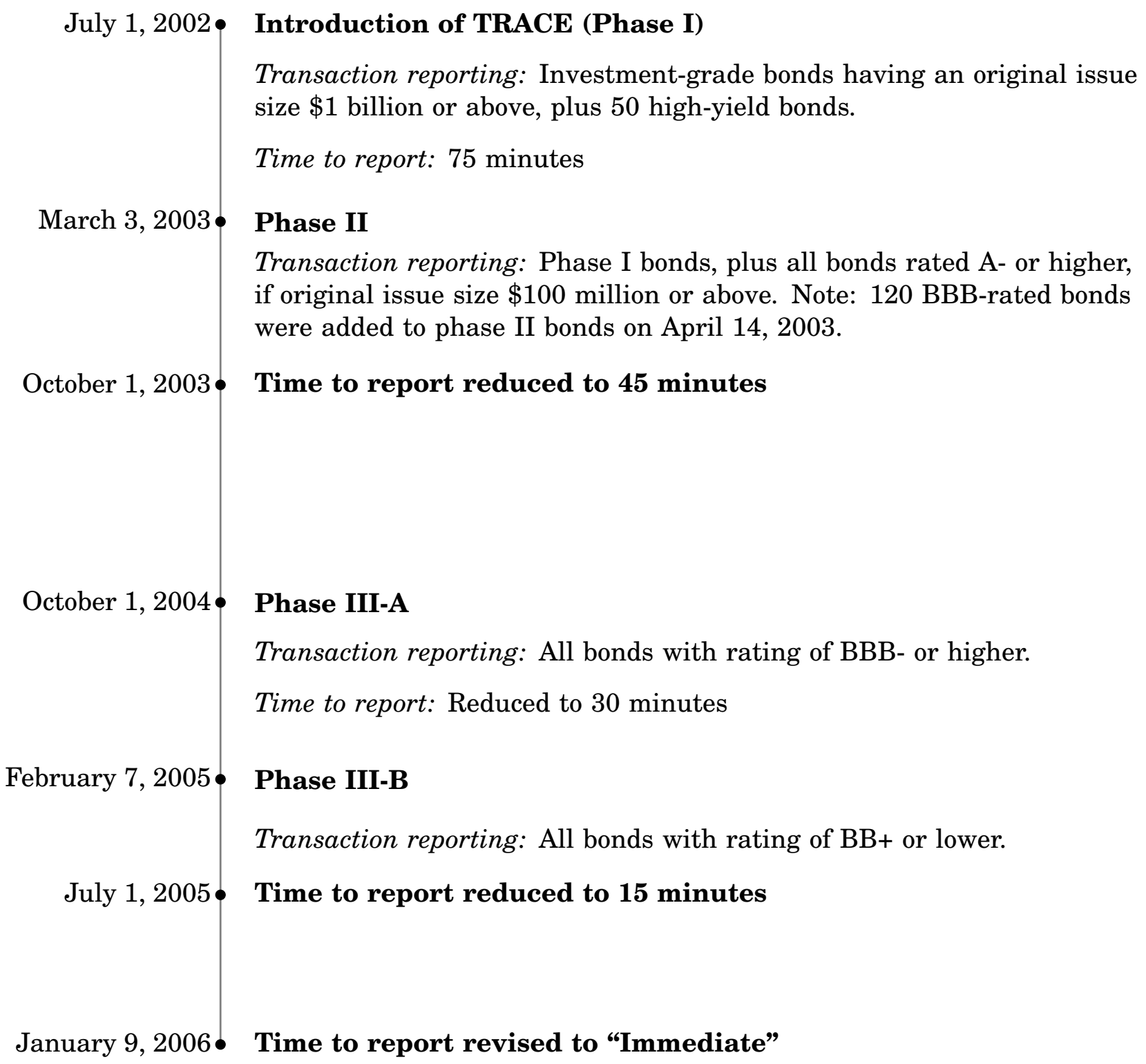

Figure 1. Time line of TRACE regulatory changes

Information from FINRA's yearly TRACE Factbooks available on finra.org. 


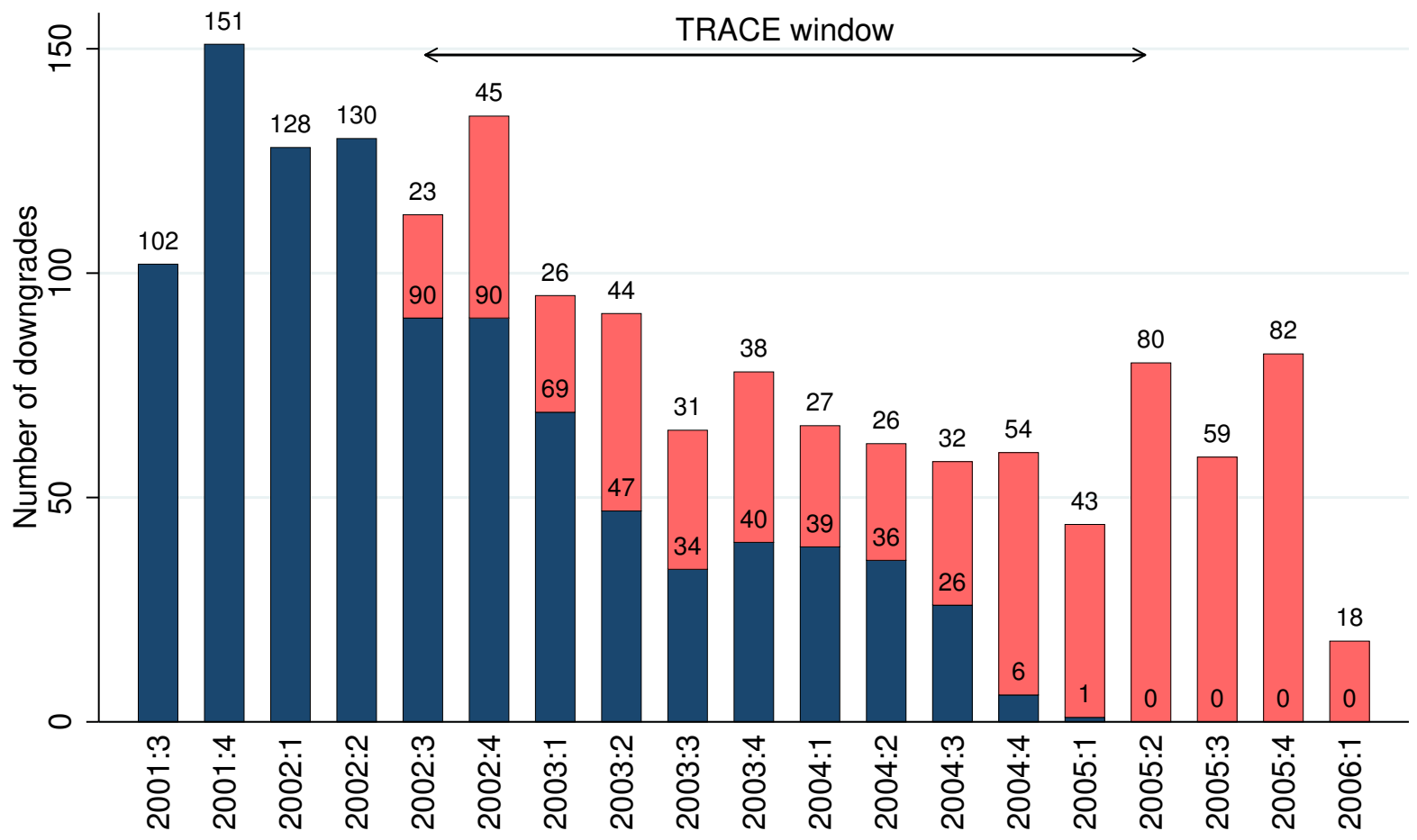

Figure 2. Distribution of sample downgrade events over time

The sample consists of 1,617 corporate bond rating downgrades by Moody's, S\&P, and Fitch during July 1, 2001 to February 7, 2006. We divide downgrades into two groups, "disseminated" (red bars) and "nondisseminated" (blue bars), based on whether or not TRACE publicly disseminated transactions in any of the issuer's downgraded bonds during the $(-31,-2)$ trading days before the downgrade event. The numbers on top of blue (red) bars represent the total number of downgrades of nondisseminated (disseminated) bonds. 


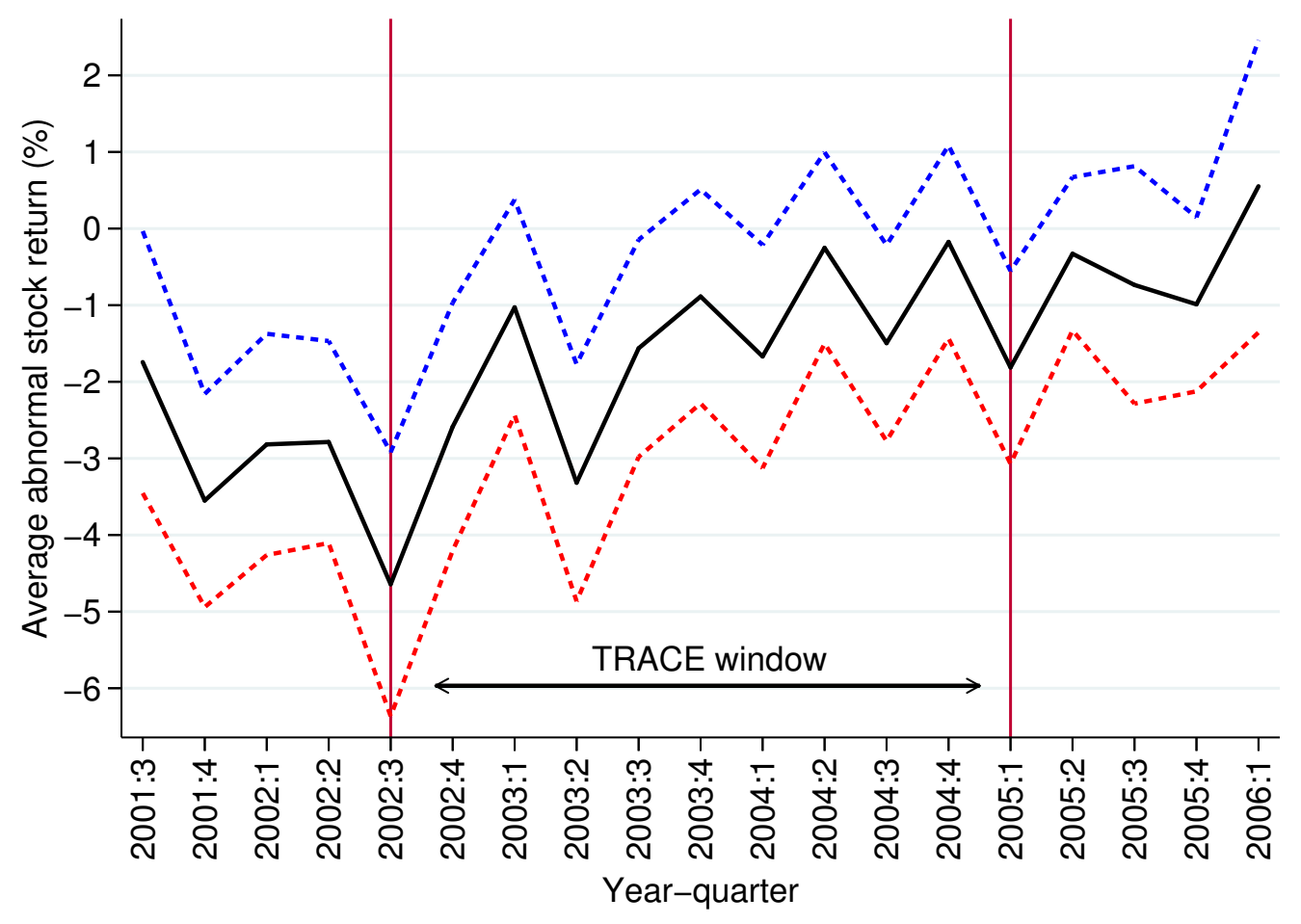

Figure 3. Quarterly average abnormal stock returns around bond rating downgrades

The sample consists of 1,617 corporate bond rating downgrades by Moody's, S\&P, and Fitch during July 1, 2001 to February 7, 2006. We use Carhart's four-factor model as the benchmark pricing model to calculate abnormal stock returns during the $(-1,+1)$ trading days centered on the date of downgrade. The estimation window is $(-251,-31)$ trading days. We require a minimum of 63 nonmissing stock returns during the estimation window and three nonmissing returns during the event window to include a downgrade in our sample. The solid line displays the quarterly average abnormal stock returns around rating downgrades, and the area between the dashed lines displays the $95 \%$ confidence interval. 


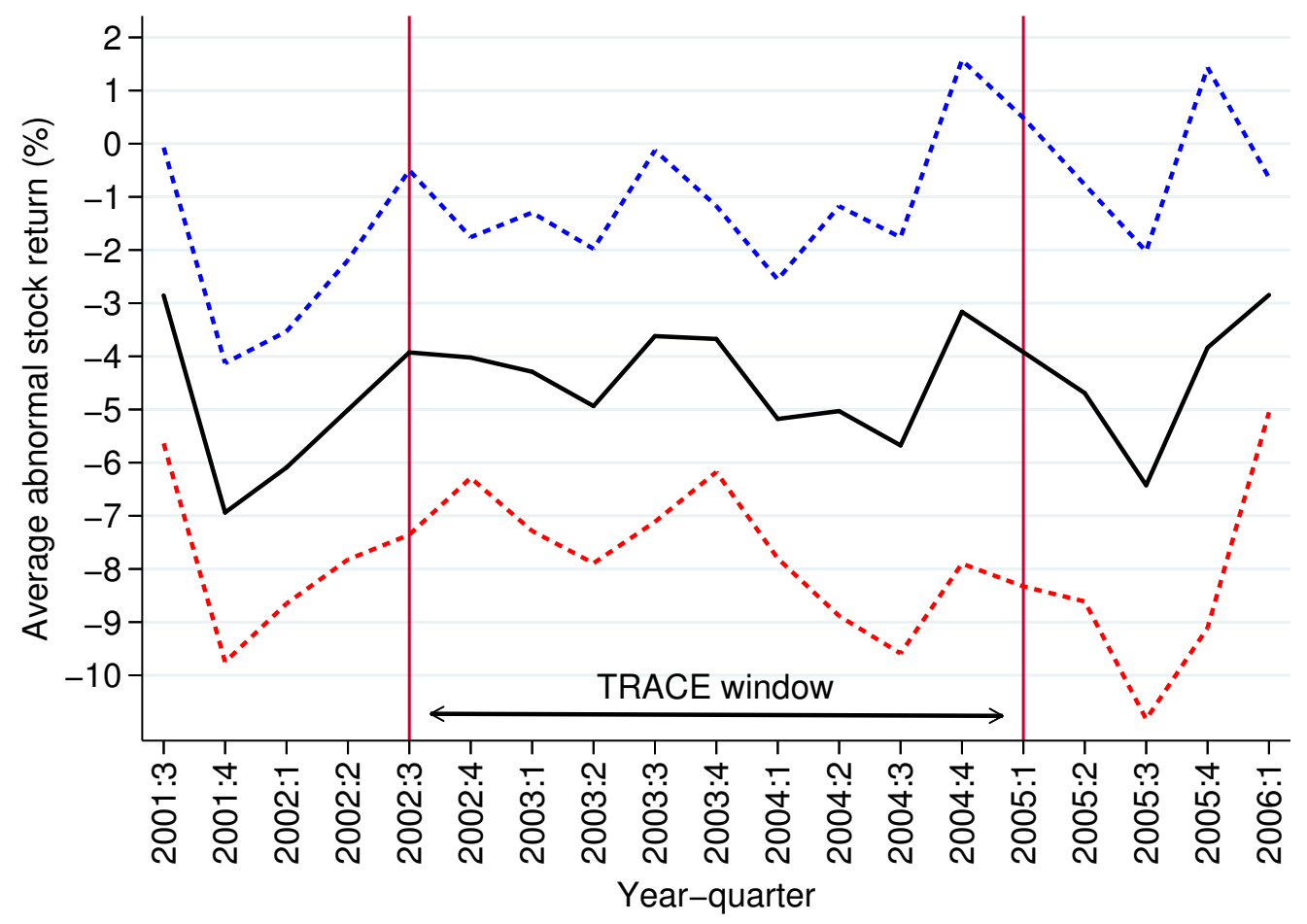

Figure 4. Quarterly average abnormal stock returns around private debt rating downgrades

The sample consists of 607 downgrades of private debt issues by S\&P between July 1, 2001 and February 7, 2006. The source of data on rating downgrades is S\&P's RatingXpress database. We count downgrades of multiple outstanding loans or private placements of an issuer on the same day only once. We further exclude downgrades by issues that were already downgraded within the preceding 7 days. We eliminate observations involving issuers that had publicly traded bonds subject to TRACE dissemination within the $(-31,-2)$ trading days preceding the ratings downgrade. The event window is $(-1,+1)$ trading days centered on the date of downgrade. The estimation window is $(-251,-31)$ trading days. We require a minimum of 63 nonmissing stock returns during the estimation window and three nonmissing returns during the event window to include a downgrade in our sample. The solid line displays the quarterly average abnormal stock returns around rating downgrades, and the area between the dashed lines displays the $95 \%$ confidence interval. 


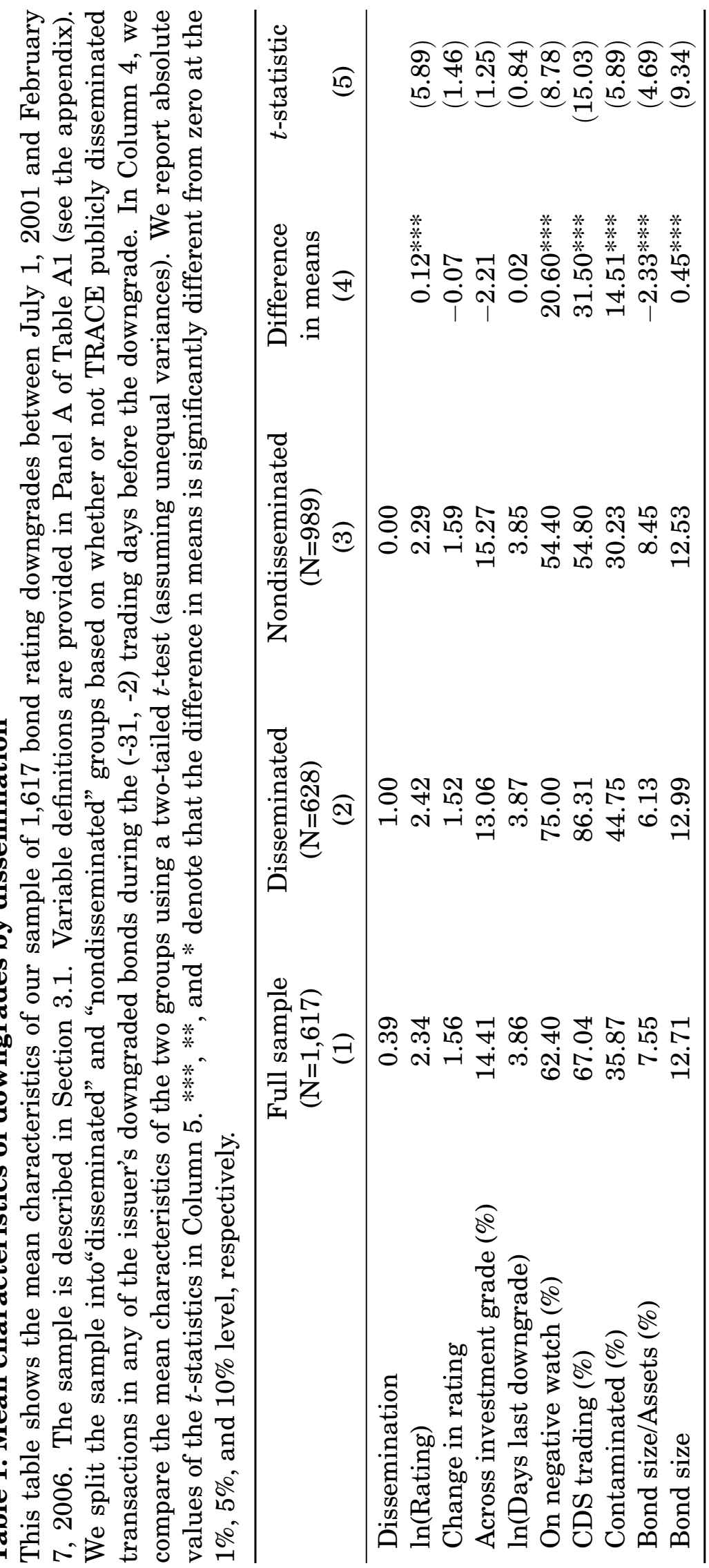




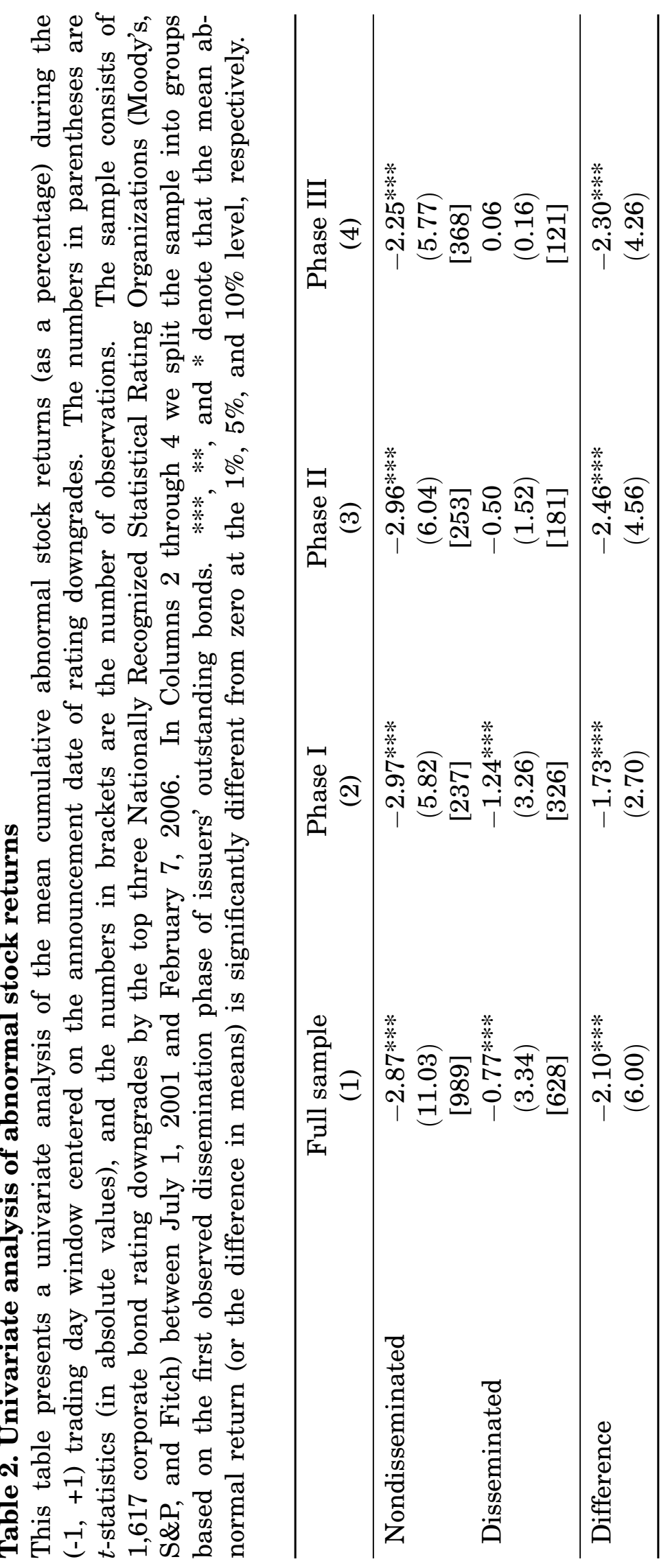


Table 3. Multivariate analysis of abnormal stock returns

This table presents ordinary least squares regressions of cumulative abnormal stock returns (as a percentage) during the $(-1,+1)$ trading day window centered on the announcement date of rating downgrades. Absolute values of $t$-statistics based on standard errors that are heteroscedasticity-consistent and clustered at the firm level are reported in parentheses beneath coefficient estimates. ***, **, and * denote that the coefficient estimate is significantly different from zero at the $1 \%, 5 \%$, and $10 \%$ level, respectively. Panel A of Table A1 (see the appendix) provides the variable definitions.

\begin{tabular}{|c|c|c|c|c|c|c|}
\hline & \multicolumn{3}{|c|}{ Full sample } & \multirow{2}{*}{$\begin{array}{c}\text { Clean } \\
\text { sample } \\
(4)\end{array}$} & \multirow{2}{*}{$\begin{array}{c}\text { Std. } \\
\text { CAR } \\
(5)\end{array}$} & \multirow{2}{*}{$\begin{array}{c}\text { Within } \\
6 \text { months } \\
\quad(6)\end{array}$} \\
\hline & (1) & $(2)$ & (3) & & & \\
\hline Dissemination & $\begin{array}{l}2.10 * * * \\
(5.60)\end{array}$ & $\begin{array}{l}2.76^{* * *} \\
(3.92)\end{array}$ & & $\begin{array}{l}1.97 * * \\
(2.14)\end{array}$ & $\begin{array}{l}44.15^{* * * *} \\
(3.23)\end{array}$ & $\begin{array}{l}3.41 * * \\
(2.08)\end{array}$ \\
\hline Dissemination $\mathrm{x}$ Phase $\mathrm{I}$ & & & $\begin{array}{l}2.75^{* * * *} \\
(3.51)\end{array}$ & & & \\
\hline Dissemination $\mathrm{x}$ Phase II & & & $\begin{array}{l}2.02^{* * *} \\
(2.49)\end{array}$ & & & \\
\hline Dissemination $\mathrm{x}$ Phase III & & & $\begin{array}{l}4.18^{* * * *} \\
(3.11)\end{array}$ & & & \\
\hline $\ln$ (Rating) & & $\begin{array}{l}1.03 \\
(0.64)\end{array}$ & $\begin{array}{l}1.05 \\
(0.66)\end{array}$ & $\begin{array}{c}3.09 \\
(1.32)\end{array}$ & $\begin{array}{c}-8.83 \\
(0.44)\end{array}$ & $\begin{array}{c}-3.02 \\
(1.01)\end{array}$ \\
\hline Change in rating & & $\begin{array}{c}0.02 \\
(0.07)\end{array}$ & $\begin{array}{c}0.01 \\
(0.05)\end{array}$ & $\begin{array}{c}-0.20 \\
(0.50)\end{array}$ & $\begin{array}{c}-1.82 \\
(0.39)\end{array}$ & $\begin{array}{c}0.96 \\
(1.21)\end{array}$ \\
\hline Across investment grade & & $\begin{array}{c}-1.83^{* *} \\
(2.46)\end{array}$ & $\begin{array}{c}-1.80 * * \\
(2.40)\end{array}$ & $\begin{array}{c}-1.48 \\
(1.29)\end{array}$ & $\begin{array}{c}-30.98^{* *} \\
(2.28)\end{array}$ & $\begin{array}{c}-1.87 \\
(0.97)\end{array}$ \\
\hline $\ln$ (Days last downgrade) & & $\begin{array}{c}-0.90^{* *} \\
(2.04)\end{array}$ & $\begin{array}{c}-0.92^{* *} \\
(2.08)\end{array}$ & $\begin{array}{c}-1.31^{* *} \\
(2.07)\end{array}$ & $\begin{array}{r}-12.02 \\
(1.60)\end{array}$ & $\begin{array}{c}0.01 \\
(0.01)\end{array}$ \\
\hline On negative watch & & $\begin{array}{c}0.32 \\
(0.53)\end{array}$ & $\begin{array}{c}0.38 \\
(0.62)\end{array}$ & $\begin{array}{c}0.32 \\
(0.45)\end{array}$ & $\begin{array}{c}12.38 \\
(1.12)\end{array}$ & $\begin{array}{c}1.45 \\
(0.73)\end{array}$ \\
\hline CDS trading & & $\begin{array}{c}-1.32 \\
(1.57)\end{array}$ & $\begin{array}{c}-1.39 \\
(1.62)\end{array}$ & $\begin{array}{c}-0.89 \\
(1.07)\end{array}$ & $\begin{array}{r}-32.57^{*} \\
(1.83)\end{array}$ & $\begin{array}{c}-1.35 \\
(0.28)\end{array}$ \\
\hline Contaminated & & $\begin{array}{l}-1.41^{* * *} \\
(2.64)\end{array}$ & $\begin{array}{c}-1.40 * * * \\
(2.64)\end{array}$ & & $\begin{array}{c}-21.12^{* *} \\
(2.10)\end{array}$ & $\begin{array}{c}-0.28 \\
(0.20)\end{array}$ \\
\hline Bond size/Assets (\%) & & $\begin{array}{c}-0.10 \\
(0.92)\end{array}$ & $\begin{array}{c}-0.09 \\
(0.93)\end{array}$ & $\begin{array}{c}-0.13 \\
(1.17)\end{array}$ & $\begin{array}{c}-2.21 \\
(1.34)\end{array}$ & $\begin{array}{c}-0.87 \text { *** } \\
(6.17)\end{array}$ \\
\hline Bond size & & $\begin{array}{c}3.45 \\
(1.33)\end{array}$ & $\begin{array}{c}3.95 \\
(1.57)\end{array}$ & $\begin{array}{c}5.53 \\
(1.33)\end{array}$ & $\begin{array}{c}49.07 \\
(0.87)\end{array}$ & $\begin{array}{l}11.07 \\
(1.39)\end{array}$ \\
\hline Bond size $^{2}$ & & $\begin{array}{r}-0.16 \\
(1.36)\end{array}$ & $\begin{array}{r}-0.17 \\
(1.54)\end{array}$ & $\begin{array}{c}-0.25 \\
(1.34)\end{array}$ & $\begin{array}{r}-2.27 \\
(0.91)\end{array}$ & $\begin{array}{r}-0.43 \\
(1.32)\end{array}$ \\
\hline Firm FEs & $\mathrm{N}$ & $\mathrm{Y}$ & $\mathrm{Y}$ & $\mathrm{Y}$ & $\mathrm{Y}$ & $\mathrm{Y}$ \\
\hline Year-quarter FEs & $\mathrm{N}$ & $\mathrm{Y}$ & $\mathrm{Y}$ & $\mathrm{Y}$ & $\mathrm{Y}$ & $\mathrm{Y}$ \\
\hline $\mathrm{N}$ & 1,617 & 1,617 & 1,617 & 1,037 & 1,617 & 377 \\
\hline$R^{2}$ & 0.02 & 0.34 & 0.34 & 0.44 & 0.32 & 0.52 \\
\hline
\end{tabular}




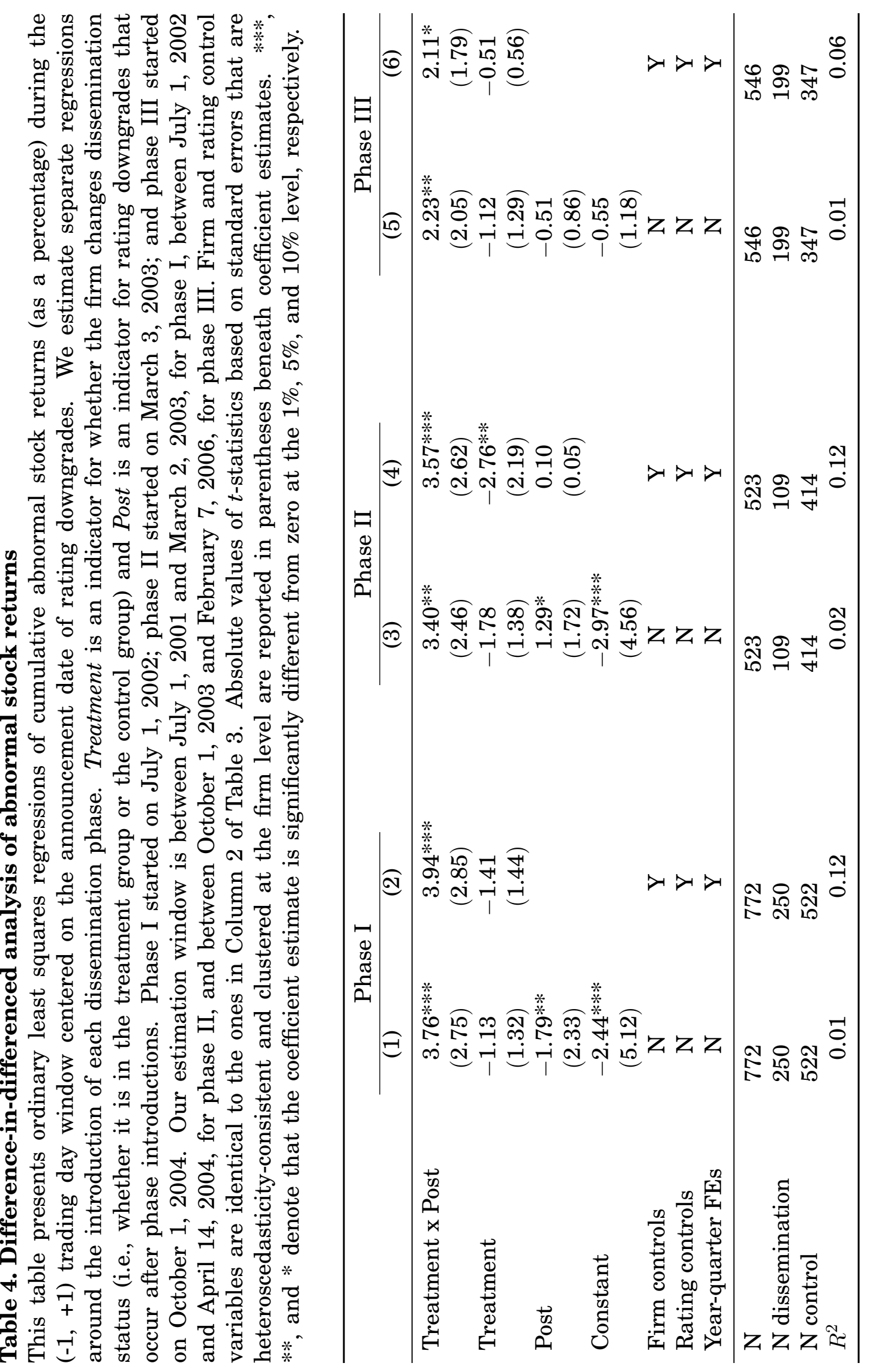




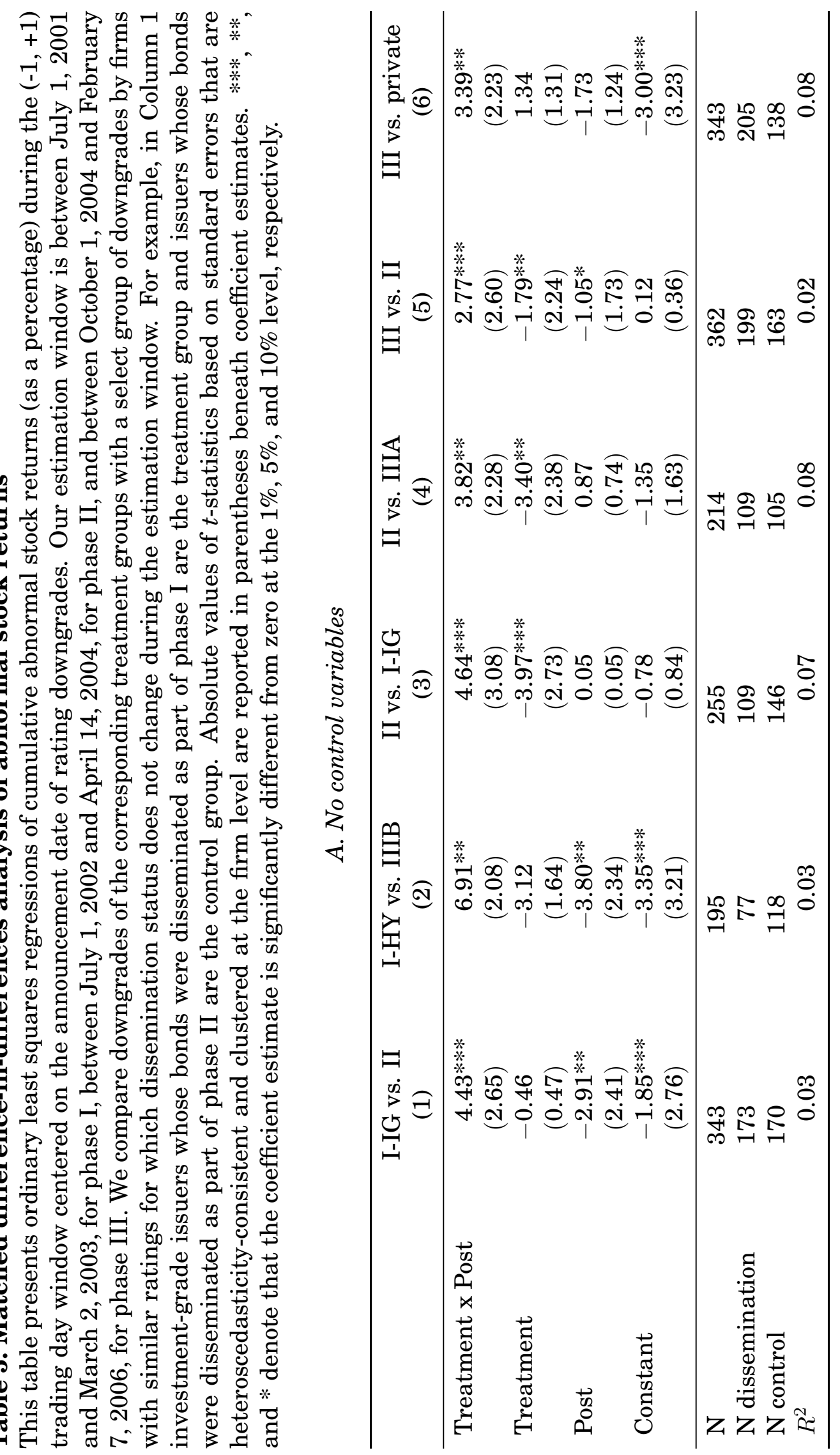




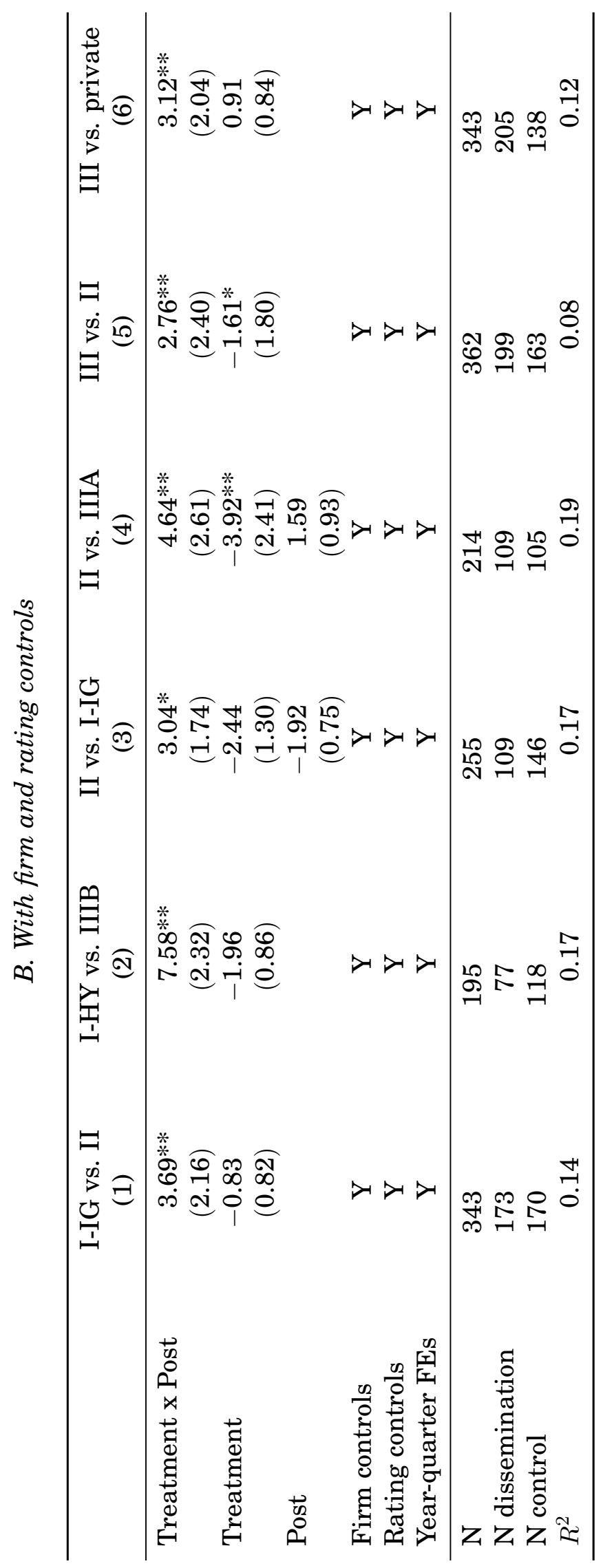


Table 6. Downgrades of investor-paid Egan Jones ratings

We estimate the effect of dissemination on abnormal stock returns associated with downgrades of investor-paid Egan-Jones (EJR) ratings using OLS regressions. The sample consists of 919 downgrades of issuer (i.e., firm-level) ratings by EJR between July 1, 2001 and February 7, 2006. To have a sample that is consistent with the samples in previous tables, we restrict the sample to issuers with at least one bond rating downgrade or upgrade in Mergent's Fixed Income Securities Database (FISD) during the sample period. The unit of observation is a firm rating event. Dissemination equals one if the firm has any outstanding bond whose transactions are disseminated via TRACE during the $(-31,-2)$ trading days preceding the downgrade. Firm and rating controls are the same as those used in Column 2 of Table 3. Absolute values of $t$-statistics based on standard errors that are heteroscedasticity-consistent and clustered at the firm level are reported in parentheses beneath coefficient estimates. ***, **, and * denote that the coefficient estimate is significantly different from zero at the $1 \%, 5 \%$, and $10 \%$ level, respectively.

\begin{tabular}{llccccc}
\hline & & Full sample & & Clean & Std. & Within \\
& & & & sample & CAR & 6 months \\
& $(1)$ & $(2)$ & $(3)$ & $(4)$ & $(5)$ & $(6)$ \\
\hline Dissemination & $2.68^{* * *}$ & $3.92^{* *}$ & & $3.63^{*}$ & $119.38^{* * *}$ & $11.54^{* * *}$ \\
& $(4.01)$ & $(2.54)$ & & $(1.89)$ & $(2.63)$ & $(2.79)$ \\
Dissemination x Phase I & & & $3.29^{*}$ & & & \\
& & & $(1.74)$ & & & \\
Dissemination x Phase II & & & $4.79^{* *}$ & & & \\
& & & $(2.58)$ & & & \\
Dissemination x Phase III & & & $5.10^{* *}$ & & & \\
& & & $(2.30)$ & & & $\mathrm{Y}$ \\
Firm controls & $\mathrm{N}$ & $\mathrm{Y}$ & $\mathrm{Y}$ & $\mathrm{Y}$ & $\mathrm{Y}$ & $\mathrm{Y}$ \\
Rating controls & $\mathrm{N}$ & $\mathrm{Y}$ & $\mathrm{Y}$ & $\mathrm{Y}$ & $\mathrm{Y}$ & $\mathrm{Y}$ \\
Firm FEs & $\mathrm{N}$ & $\mathrm{Y}$ & $\mathrm{Y}$ & $\mathrm{Y}$ & $\mathrm{Y}$ & $\mathrm{Y}$ \\
Year-quarter FEs & $\mathrm{N}$ & $\mathrm{Y}$ & $\mathrm{Y}$ & $\mathrm{Y}$ & $\mathrm{Y}$ & $\mathrm{Y}$ \\
\hline $\mathrm{N}$ & 919 & 919 & 919 & 608 & 919 & 224 \\
$R^{2}$ & 0.02 & 0.48 & 0.48 & 0.59 & 0.48 & 0.75 \\
\hline
\end{tabular}




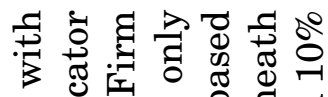
क्ष 㠃 过: :

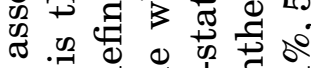

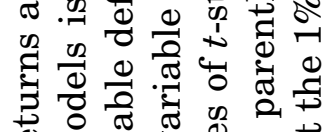

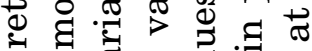
पै कै

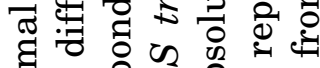

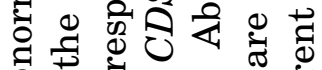
के

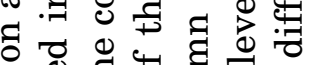
表 正 :

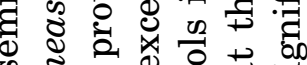
设 है

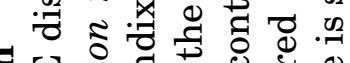

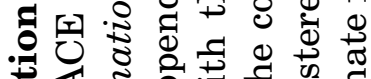

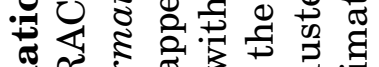
表它

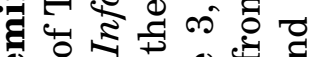
눠워

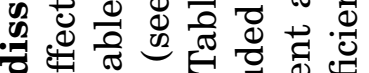
월 पै

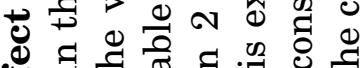

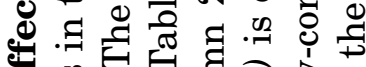

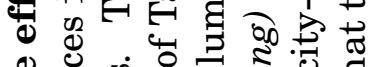
\& ن च

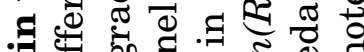
중 है न 雪 ส

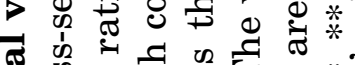
สี \% कृ क्ष

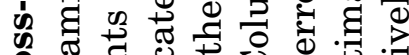
०

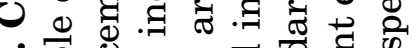
$\therefore \frac{0}{\sigma} \cong$ o

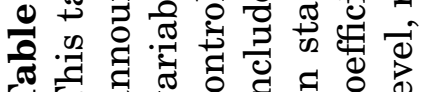

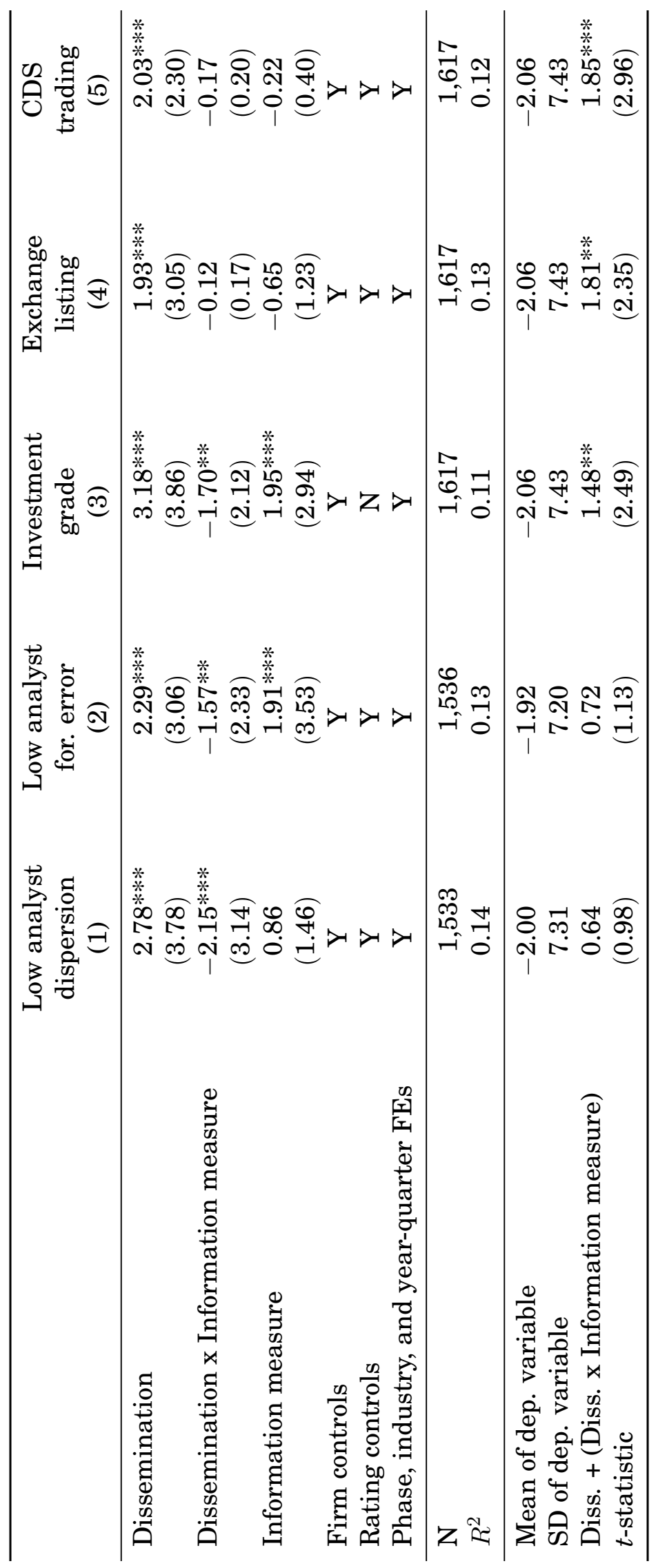




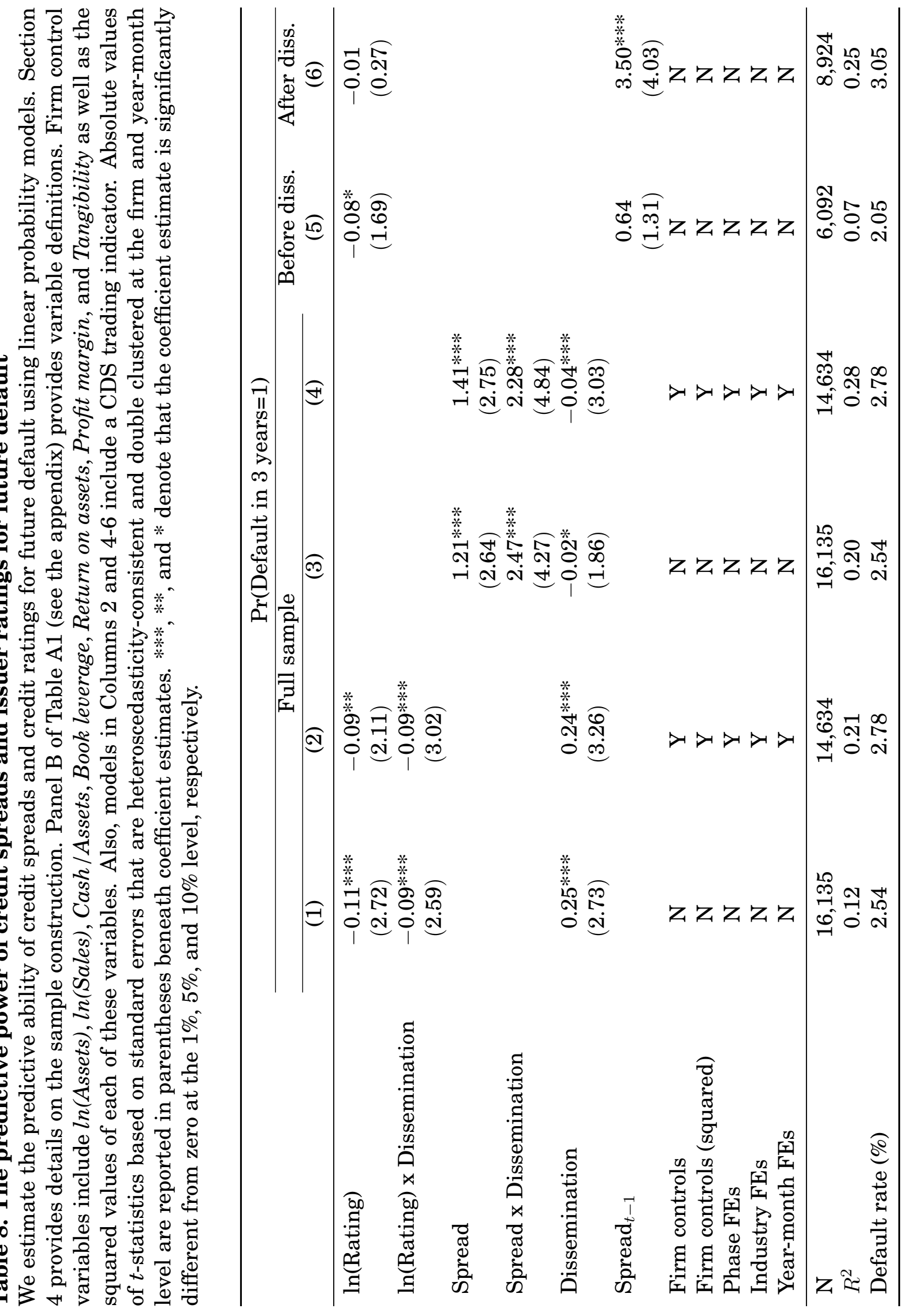




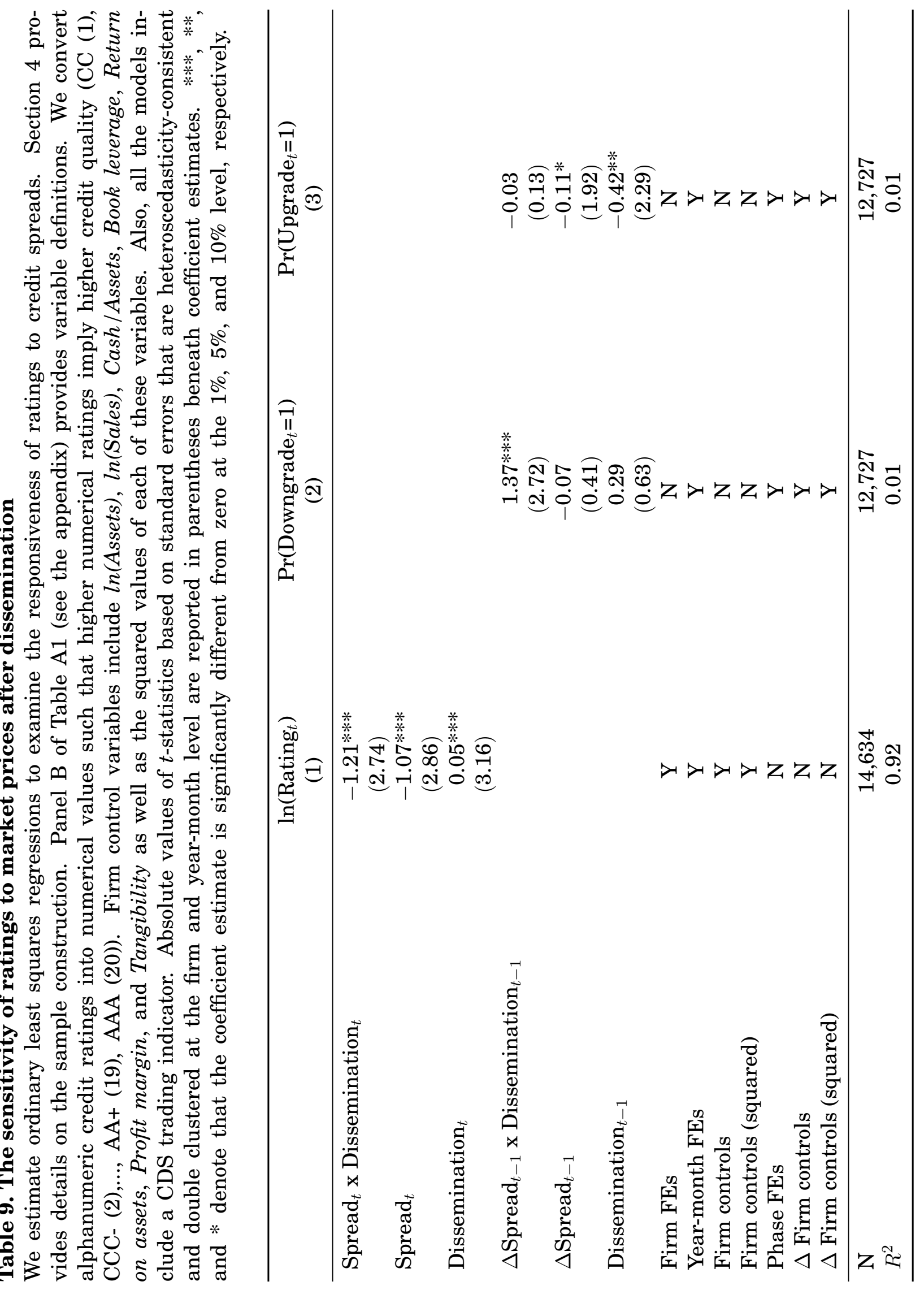

